\title{
Ability of commercially available dairy ration programs to predict duodenal flows of protein and essential amino acids in dairy cows
}

\author{
D. Pacheco, ${ }^{*}$ R. A. Patton, $\dagger^{1}$ C. Parys, $\neq$ and H. Lapierre§ \\ ${ }^{*}$ AgResearch Ltd., Grasslands Research Centre, Private Bag 11008, Palmerston North, New Zealand \\ †Nittany Dairy Nutrition, Mifflinburg, PA 17844 \\ ‡Evonik Industries AG, 63457 Hanau, Germany \\ §Dairy and Swine Research and Development Centre, Agriculture and Agri-Food Canada, Sherbrooke, QC, Canada J1M 0C8
}

\begin{abstract}
The objective of this analysis was to compare the rumen submodel predictions of 4 commonly used dairy ration programs to observed values of duodenal flows of crude protein $(\mathrm{CP})$, protein fractions, and essential AA (EAA). The literature was searched and 40 studies, including 154 diets, were used to compare observed values with those predicted by AminoCow (AC), Agricultural Modeling and Training Systems (AMTS), Cornell-Penn-Miner (CPM), and National Research Council 2001 (NRC) models. The models were evaluated based on their ability to predict the mean, their root mean square prediction error (RMSPE), error bias, and adequacy of regression equations for each protein fraction. The models predicted the mean duodenal CP flow within 5\%, with more than $90 \%$ of the variation due to random disturbance. The models also predicted within $5 \%$ the mean microbial CP flow except CPM, which overestimated it by $27 \%$. Only NRC, however, predicted mean rumen-undegraded protein (RUP) flows within 5\%, whereas AC and AMTS underpredicted it by 8 to $9 \%$ and CPM by $24 \%$. Regarding duodenal flows of individual AA, across all diets, CPM predicted substantially greater $(>10 \%)$ mean flows of Arg, His, Ile, Met, and Lys; AMTS predicted greater flow for Arg and Met, whereas AC and NRC estimations were, on average, within $10 \%$ of observed values. Overpredictions by the CPM model were mainly related to mean bias, whereas the NRC model had the highest proportion of bias in random disturbance for flows of EAA. Models tended to predict mean flows of EAA more accurately on corn silage and alfalfa diets than on grass-based diets, more accurately on corn grain-based diets than on non-corn-based diets, and finally more accurately in the mid range of diet types. The 4 models were accurate at predicting mean dry matter intake.
\end{abstract}

Received January 12, 2011.

Accepted September 18, 2011.

${ }^{1}$ Corresponding author: nittnut@aol.com
The AC, AMTS, and NRC models were all sufficiently accurate to be used for balancing EAA in dairy rations under field conditions.

Key words: dairy ration program, duodenal flow, essential amino acid, protein

\section{INTRODUCTION}

For most dairy producers, protein supplementation represents a large fraction of the cost of dairy rations. Currently, many herds are fed diets containing excess $\mathrm{CP}$, resulting in inefficient $\mathrm{N}$ use and more $\mathrm{N}$ excreted to the environment. Whether greater dietary protein concentrations are fed to ensure sufficient AA supply or as insurance against possible ingredient deficiency is not clear. It is possible to maintain high milk production $(>40 \mathrm{~kg} / \mathrm{d})$ on diets of approximately $15 \% \mathrm{CP}$ with a resulting reduction in $\mathrm{N}$ excretion compared with an $18.5 \%$ CP diet, when balanced for AA supply rather than CP level (Broderick et al., 2008). However, this result is not consistently obtained (Broderick et al., 2009), and a possible explanation may be inadequate AA supply with the low CP diet due to inaccurate estimation of the supply of total protein or digestive flow of some individual essential AA (EAA). Nutritionists are also concerned that models have been developed mostly using corn-based diets, and therefore may only predict well for high grain diets and are less accurate on low concentrate diets or diets based on forages other than corn silage and alfalfa.

Numerous models of rumen and animal metabolism with different degrees of mechanistic representation have been authored and used around the world (e.g., Baldwin et al., 1987; Dijkstra et al., 1992; Sniffen et al., 1992; Lescoat and Sauvant, 1995; Fox et al., 2004). All of these models can predict protein flow from the rumen based on ration composition and intake but, with the exception of the Cornell Net Carbohydrate-Protein System (CNCPS), are generally considered too complicated for field use. Four models, derived in various ways from the models referred to above, are designed 
to predict MP and metabolizable (or digested) AA and are widely used commercially in North America. They are (1) AminoCow (AC) version 3.5.2; Evonik AG Industries, Hanau, Germany; (2) Agricultural Modeling and Training Systems LLC (AMTS) version 2.0.15, Cortland, NY; a variation of the CNCPS; (3) Cornell-Penn-Miner (CPM), an earlier variation of CNCPS, version 3.0.1, published by Cornell University, Ithaca, NY; University of Pennsylvania, Philadelphia, PA; Miner Institute, Chazy, NY; and University of Maryland, College Park, cooperating; and (4) Nutrient Requirements of Dairy Cattle (NRC, 2001; 7th rev. ed., version 1.01) published by the National Research Council, Washington, DC (NRC). The CPM model is an early commercial version of the CNCPS (Sniffen et al., 1992; Fox et al., 2004) but is still widely used and thus is included in this evaluation. The AMTS model represents one of the newest commercially available versions of CNCPS. Despite their wide usage and published comparisons for some nutrient predictions among CNCPS (Kohn et al., 1998; Kolver et al., 1998; Von Keyserlingk et al., 1999) and other models (Bateman et al., 2001; Yu et al., 2003; Patton, 2010), to our knowledge, these models have not been compared for their ability to predict duodenal flow of total CP, microbial CP, RUP, and EAA on a broad set of dairy rations. Despite validation of these different models by researchers before release, a straight comparison of their predictions may provide impetus for greater use of AA balance among field nutritionists should these models be proven to accurately predict the duodenal flow of protein fractions and EAA across a wide range of feeding conditions.

Therefore, the purposes of this study were (1) to compare predictions of duodenal $\mathrm{CP}$, its distribution between microbial CP and RUP, and EAA flows with those reported in the literature; and (2) to identify if any diet types affected the accuracy of prediction among models.

\section{MATERIALS AND METHODS}

Google Scholar and Agricola databases were searched for studies published in refereed journals that reported treatment means of $\mathrm{CP}$, microbial $\mathrm{CP}$, RUP, and individual EAA flows to the duodenum. Only studies that utilized dietary treatments were included in this data set. This resulted in final identification of 40 separate studies representing 154 diets; the references are listed in the Appendix. All information for feed amounts, milk production, and BW were entered into the 4 models. When BW was not reported or could not be calculated (4 studies), default BW were taken from the NRC model for the parity reported. In studies in which mixed parities were reported, second lactation was entered in the models. Likewise, BCS was entered when reported; otherwise, a BCS of 2.75 was assumed. Virtually all studies reported total ration $\mathrm{CP}, \mathrm{NDF}, \mathrm{NE}_{\mathrm{L}}$, and $\mathrm{OM}$, or these values could be calculated from other information in the study. Nutrient composition for individual feed ingredients was entered if reported. When a nutrient of an individual feed was unreported, the NRC default values for $\mathrm{CP}, \mathrm{NDF}, \mathrm{ADF}$, ether extract, neutral detergent insoluble $\mathrm{CP}$, acid detergent insoluble $\mathrm{CP}$, lignin, and ash were used. When nutritional composition of feed ingredients was not reported, forage nutrient composition was adjusted to match the total nutrient composition reported for the diets. The specific model default values were used for protein fractions, degradation rates, passage rates, and EAA composition in the case of NRC, AMTS, and CPM, except that AA content was entered in NRC when provided. For the AC model RUP and EAA, default composition was used, unless AA composition was reported. For AMTS and CPM, the AA composition of the undegradable protein was not adjusted even when AA composition of the ingredients was reported because these programs both use AA values for undegraded protein and these values are not well reported in the literature. Rather than assuming erroneous calculations, the default values were used. Nutrient content entered into each model was the same except for diets in which animal proteins were fed. In this case, the NDF as calculated by AMTS and CPM differed from that in the other models. This is because AMTS and CPM report NDF for these feeds, whereas AC and NRC do not report these feeds as having cell wall constituents. However, because AMTS and CPM need these values to function, they were left unadjusted. The AC model provides the option to adjust the calculated MP based on the amount of rumen RDP; this option was used for all diets. The energy calculations were unadjusted for each model. Our purpose in standardizing feed nutrient composition was to measure differences in the model prediction of AA flow rather than to evaluate the influence of compositional differences in the model databases. The CP flow to the small intestine for the observed values was calculated as NAN $\times 6.25$. For observed data, microbial $\mathrm{CP}$ was estimated as microbial $\mathrm{N} \times 6.25$; for simplicity, observed RUP flow was calculated as (NAN flowing to the duodenum - microbial $\mathrm{N}) \times 6.25$, and therefore includes contribution of endogenous secretions. The definition of protein fractions contributing to duodenal CP flow differed between models. For the AMTS and CPM model, duodenal CP flow was assumed to consist only of microbial CP plus RUP, the endogenous contribution being ignored (O'Connor et al., 1993; Fox et al., 2004; Tylutki et al., 2008), whereas for the AC and 
NRC models, the presence of endogenous secretions was acknowledged and RUP was therefore calculated as [duodenal CP flow - (microbial CP + endogenous flow)]. Endogenous protein was calculated as $11.87 \times$ DMI for AC (Evonik Degussa GmbH, 2007a) and as $1.9 \times \mathrm{DMI} \times 6.25$ for the NRC model $(\mathrm{NRC}, 2001)$. To allow comparison of similar terms, RUP is defined in the current analysis as the model-reported RUP plus the endogenous protein for the AC and NRC models, whereas for AMTS and CPM, RUP is defined as the model-reported RUP. The AC model does not directly predict AA intestinal flow, but because of an assumed constant digestibility of duodenal AA to metabolizable AA of $80 \%$, duodenal flow was calculated as metabolizable AA/0.8 (Evonik Degussa GmbH, 2007b). Other fractions for all models were recorded as reported by the individual models.

To investigate the effect of various ration types and ingredient types on duodenal flows, diets were grouped as follows. Diet groups based on forage types were (1) diets in which grass was the major forage (more than $50 \%$ of forage DMI) whether offered as pasture, silage or hay $(\mathrm{n}=23)$; (2) diets in which corn silage was the major forage $(\mathrm{n}=68)$; $(3)$ diets in which alfalfa, offered as either silage or hay, was the major forage (n $=36$ ). Diets were grouped on major source of NFC as either corn grain-based diets, including high-moisture corn, dry rolled corn, cracked corn, steam-rolled corn, and ground corn $(\mathrm{n}=107)$, or non-corn-based diets $(\mathrm{n}=43)$. This group contained mostly grains such as ground barley, steam-rolled barley, and ground wheat, but also contained beet pulp and molasses. Diets were also categorized according to inclusion or not of RUP source for different types of protein normally thought of as providing high RUP. A significant number of diets had no RUP source added $(\mathrm{n}=60)$. Diets used in this study were also stratified by DMI as low (DMI $<17$ $\mathrm{kg} / \mathrm{d} ; \mathrm{n}=45)$ and high $(\mathrm{DMI}>22 \mathrm{~kg} / \mathrm{d} ; \mathrm{n}=42)$ and by protein content into low $\mathrm{CP}(14.5 \pm 1.2 \% \mathrm{DM} ; \mathrm{n}=41)$, and high CP $(18.3 \pm 0.9 \% \mathrm{DM} ; \mathrm{n}=55)$. Finally, diets were stratified by NDF content into low NDF $(27.1 \pm$ $2.1 \% \mathrm{DM} ; \mathrm{n}=48)$, and high NDF $(38.3 \pm 4.9 \% \mathrm{DM}$; $\mathrm{n}=55)$.

Statistical analyses similar to that reported by Bateman et al. (2001) as modified by Pacheco et al. (2006) were applied. Briefly, observed and predicted values from the 4 models were compared using regression analyses from the Mixed procedure of SAS (version 8.0; SAS Institute Inc., Cary, NC), including study as a random effect (St-Pierre, 2001). Calculations of root mean square prediction error (RMSPE) and the relative prediction error (RPE: RMSPE as a percentage of the observed mean) as well as the decomposition of the mean square prediction error (MSPE) into mean bias, regression bias, and random disturbance were as described by Bibby and Toutenburg (1977), also after the study effect was removed.

\section{RESULTS}

Three methods of evaluating models were considered: (1) the ability of models to predict the mean and standard error; (2) the size of RMSPE and RPE along with the appropriate apportionment of error into mean bias, regression or equation bias, and random bias; and (3) the linear regression of actual versus predicted values for closeness to unity. For presentation of results and discussion purposes, we are arbitrarily describing predictions within $5 \%$ of observed mean as very accurate, predictions within $10 \%$ as accurate, and predictions within $15 \%$ as acceptable. Outside this range, we considered model usefulness to be compromised. Descriptive statistics including means and ranges for production variables of animals in the studies used in the current analysis are reported in Table 1 . Because the coefficient of determination $\left(\mathrm{R}^{2}\right)$ is high for all models and varies little, this will not be discussed in detail, although the $\mathrm{R}^{2}$ will be reported for all protein fractions and EAA. Likewise, unless the models miss the mean by more than $15 \%$, the apportionment of error will not be discussed, but will be presented in tabular form.

\section{Across All Diets}

Protein Fractions. Across all diet types, the prediction of mean CP flow to the duodenum was predicted within $5 \%$ of the observed flow with all models (Table 2 ). Both AC and NRC predicted slightly lower flows of microbial CP than were observed, whereas AMTS predicted slightly greater microbial $\mathrm{CP}$ flow. These 3 models were all very accurate, whereas CPM predicted mean microbial $\mathrm{CP}$ flows that were more than $25 \%$ greater than observed. All models underpredicted RUP, with NRC predicting within 5\%, AC and AMTS within $10 \%$, and CPM at $76 \%$ of observed RUP. For prediction of total CP flow, AMTS exhibited the smallest RMSPE and the highest slope parameter, indicating a slightly more robust model for prediction of $\mathrm{CP}$ flow; CPM displayed the largest RMSPE, and AC had the lowest slope estimate for $\mathrm{CP}$ passage to the duodenum (Table 3). All models displayed low mean bias $(<5 \%)$ and regression bias $(<7 \%)$ for $\mathrm{CP}$ flow prediction, with more than $93 \%$ of the variation in random disturbance. The AMTS model also displayed the smallest RMSPE for flow of microbial $\mathrm{CP}$ and RUP. The AC model displayed significant regression bias for microbial $\mathrm{CP}$ (44\%), whereas CPM bias was toward the mean (57\%). In accordance with an overprediction of microbial CP, 
Table 1. Descriptive statistics for studies used in determination of duodenal flow of protein and essential AA of adult dairy cattle

\begin{tabular}{lccccc}
\hline Item & $\begin{array}{c}\text { No. of } \\
\text { diets }\end{array}$ & Mean & SD & Minimum & Maximum \\
\hline DMI, kg/d & 154 & 19.1 & 3.8 & 9.1 & 26.7 \\
CP, \% of DM & 154 & 16.6 & 1.8 & 10.5 & 23.6 \\
NDF, \% of DM & 154 & 32.4 & 5.6 & 21.7 & 53.2 \\
Forage in diet, \% & 154 & 49.5 & 12.6 & 28.0 & 100.0 \\
BW, kg & 154 & 596 & 51 & 410 & 717 \\
Milk yield, kg/d & 103 & 29.5 & 6.9 & 13.0 & 41.7 \\
Milk CP, \% & 103 & 3.12 & 0.22 & 2.69 & 3.69 \\
DIM & 103 & 135.6 & 58.6 & 50 & 250 \\
\hline
\end{tabular}

CPM displayed a large mean bias $(29 \%)$ for the RUP predictions and the highest RMSPE for RUP.

Individual $\boldsymbol{A} \boldsymbol{A}$. Across all diets, mean Arg was predicted very accurately by AC and NRC but overpredicted by $25 \%$ by AMTS and by $31 \%$ by CPM. The RMSPE was similar between the models, but AMTS and CPM both displayed a large mean bias for the prediction of Arg duodenal flow (40 and 53\%, respectively; Table 3). Means of His flows were underpredicted by AC (4\%) and NRC (8\%) and overpredicted by AMTS $(8 \%)$ and $\mathrm{CPM}(13 \%)$. Isoleucine was overpredicted from 6 to $13 \%$ by AC, AMTS, and CPM, but not by NRC. Leucine was underpredicted by all models but was within $5 \%$. Lysine was also slightly overpredicted $(<5 \%)$ by all models except for CPM, which predicted only acceptably. Methionine was overpredicted by $26 \%$ by CPM, acceptably by AMTS, and very accurately by AC and NRC. The AMTS model had a slight mean bias (15\%) for prediction of Met, whereas CPM had a large mean bias (45\%). Phenylalanine, Thr, and Val were also well predicted by all models although CPM exhibited a slight mean bias for prediction of Phe (16\%). Across all AA, with the exception of Met and His, AMTS displayed the lowest RMSPE. Considering the prediction of EAA over all diets, the NRC model had the highest average percentage of random error (97\%), whereas CPM had the lowest random error $(72 \%)$. The CPM model displayed a mean bias for almost all AA, which on average represented $22 \%$ of the bias partition. On average, the AC model had the highest bias toward the slope and had the lowest slopes. The models displayed similar RMSPE (Table 3).

\section{Effect of Forage Sources}

Protein Fractions. All models predicted that duodenal flows of CP, microbial CP, and RUP increased as diets changed from grass-based to corn silage-based to alfalfa-based diets (Tables 4, 5, and 6). Duodenal flows of $\mathrm{CP}$ for the different forage diets were predicted very accurately, except for $\mathrm{CPM}$ in which $\mathrm{CP}$ flow was overpredicted by 13 and $6 \%$ for grass-based and corn silage-based diets, respectively. It is also of interest that for diets based on corn silage and alfalfa, the flow of observed microbial CP was roughly equal to observed RUP, whereas for grass-based diets, the RUP was reduced to about $60 \%$ of the microbial CP. The proportion between microbial CP and RUP was well predicted in corn silage-based diets by $\mathrm{AC}$ and NRC and to a lesser extent by AMTS; the 3 models also predicted a decrease of this proportion on grass-based diets, but of smaller magnitude than the observed values. Overall, microbial CP was accurately predicted by AC, AMTS, and NRC for all diet types, except for grass-based diets for NRC in which underprediction of $12 \%$ was present. The CPM model overpredicted microbial CP flows by 14,28 , and $32 \%$ for grass-, alfalfa-, and corn silage-based diets, respectively. With the exception of NRC with corn silage-based diets, RUP was never very accurately predicted. The RUP flow of grass-based diets was overpredicted by all models, from 9 to $17 \%$. On the other hand, RUP flow was underpredicted by all models for alfalfa-based diets, although AMTS and NRC predicted within acceptable limits. Similarly, the RUP fraction of corn silage-based diets was also underpredicted by the 4 models, with NRC having the best agreement (97\%) and CPM the worst (75\%). Partitioning of error for alfalfa or corn silage diets indicated that approximately $70 \%$ of error ascribed to CPM was due to a mean bias for microbial CP, whereas between 36 and $42 \%$ of the RUP error was also mean bias (Tables 4, 5, and 6).

Individual $\boldsymbol{A} \boldsymbol{A}$. For grass-based diets, only AMTS predicted Arg within 10\%, and CPM within 15\%. The $\mathrm{AC}$ and NRC underpredictions of Arg were not in a useful range (19 and 21\%, respectively). All models predicted His flow to be less than observed, with only CPM predicting His flow accurately and AMTS predicting in an acceptable range. Both $\mathrm{AC}(21 \%)$ and NRC $(23 \%)$ predicted His flow less than acceptably. Other than Met, which was predicted $18 \%$ high by the CPM model, predictions of other EAA were sufficiently accurate. The MSPE decomposition for Arg and His 


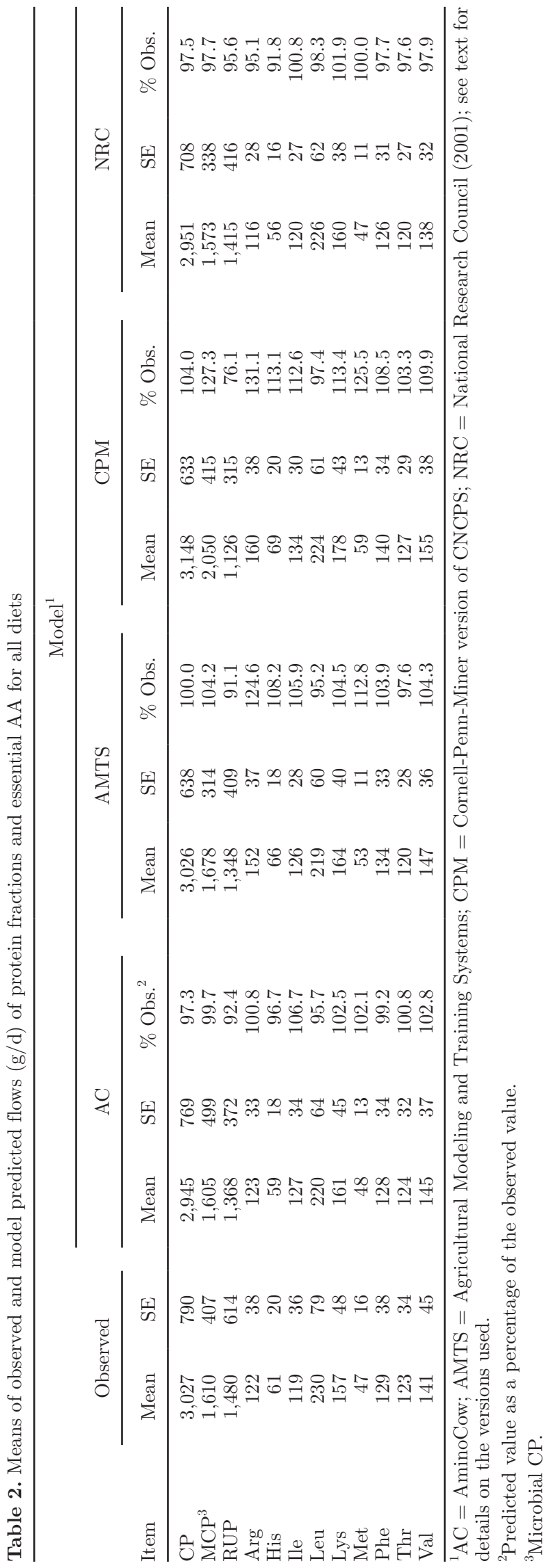

revealed no serious bias although the mean bias was greater for these $2 \mathrm{AA}$ than for all the other EAA. Apportionment of error for Met prediction indicated that the CPM model had both an $18 \%$ mean bias and an $8 \%$ regression bias (Tables 4,5 , and 6 ). For grassbased diets, RMSPE and $\mathrm{R}^{2}$ were similar among model predictions. For these diets, CPM generally displayed the lowest RMSPE and NRC the highest.

For predictions of AA in alfalfa-based diets, Arg was overpredicted $27 \%$ by AMTS and $33 \%$ by CPM. Similarly, Met was overpredicted $17 \%$ by AMTS and $34 \%$ by CPM. Error decomposition for Arg indicated that $65 \%$ of the MSPE in AMTS and $75 \%$ in CPM were due to mean biases, whereas for Met the mean bias was 34 and $64 \%$ for AMTS and CPM, respectively. Histidine, Ile, Leu, Lys, Phe, Thr, and Val were predicted within accurate limits by the 4 models. For alfalfa-based diets, AMTS displayed the lowest MSPE and NRC the highest across all amino acids.

Duodenal flows of EAA with corn silage-based diets were all predicted within accurate limits by $\mathrm{AC}$ and NRC. Arginine was overpredicted by $26 \%$ by AMTS and $32 \%$ by CPM, and CPM overpredicted His by $19 \%$ and Met by $20 \%$ (Tables 4, 5, and 6). Partition of error revealed that CPM had a mean bias of $64 \%$ for Arg, $42 \%$ for His, and $38 \%$ for Met on the corn silage-based diets. The AMTS model displayed a mean bias of $52 \%$ for Arg. For corn silage diets, AC displayed the lowest RMSPE and CPM the highest.

Overall, with grass-based diets, the ratio of predicted:observed duodenal flows of EAA was always smaller than the ratio of predicted:observed CP flows, whereas the opposite was observed with alfalfa- and corn silage-based diets (except for NRC predictions of corn silage-based diets). Leucine duodenal flows were slightly $(<5 \%)$ underpredicted with grass-based diets. A greater $(<10 \%)$ underprediction was obtained for alfalfa- and corn silage-based diets (except NRC for corn silage).

For grass-based diets, AC displayed the lowest RMSPE for both protein fractions and EAA, whereas CPM had the highest. In alfalfa-based diets, AMTS displayed the lowest RMSPE and CPM the highest, whereas in corn silage-based diets, AMTS had the lowest RMSPE for protein fractions, but $\mathrm{AC}$ the lowest for EAA. In these diets, CPM displayed the largest RMSPE for both.

\section{Effect of Carbohydrate Sources}

Protein Fractions. All models predicted CP flow of non-corn-based diets within accurate limits, whereas the $\mathrm{CP}$ flow of corn-based diets was estimated more precisely (Tables 7 and 8). For the non-corn-based diets, 
Table 3. Model adequacy statistics for comparison of model predicted versus observed values for all diets

\begin{tabular}{|c|c|c|c|c|c|c|c|c|c|}
\hline Model $^{1}$ & Item & $\mathrm{RMSPE}^{2}$ & $\mathrm{RPE}^{2}$ & $\mathrm{R}^{2}$ & Int. $^{3}$ & Slope & \multicolumn{3}{|c|}{ MSPE bias partition ${ }^{4}$} \\
\hline \multirow[t]{8}{*}{$\mathrm{AC}$} & $\mathrm{CP}$ & 175.2 & 5.8 & 0.95 & 854 & 0.73 & 0.3 & 6.5 & 93.5 \\
\hline & RUP & 179.6 & 12.1 & 0.91 & 224 & 0.89 & 5.9 & 1.0 & 93.1 \\
\hline & Arg & 11.2 & 9.2 & 0.91 & 41 & 0.65 & 0.0 & 11.9 & 88.1 \\
\hline & His & 5.6 & 9.2 & 0.92 & 14 & 0.77 & 1.2 & 10.6 & 88.2 \\
\hline & Met & 3.7 & 7.9 & 0.94 & 13 & 0.71 & 0.3 & 6.5 & 93.1 \\
\hline & Phe & 9.9 & 7.7 & 0.93 & 28 & 0.77 & 0.1 & 4.6 & 95.3 \\
\hline & Thr & 8.2 & 6.7 & 0.94 & 41 & 0.65 & 0.3 & 10.4 & 89.3 \\
\hline & Val & 9.8 & 7.0 & 0.95 & 32 & 0.74 & 0.9 & 6.4 & 92.8 \\
\hline \multirow[t]{7}{*}{ AMTS } & $\mathrm{CP}$ & 159.6 & 5.3 & 0.96 & 336 & 0.88 & 0.0 & 0.4 & 99.6 \\
\hline & Leu & 15.7 & 6.8 & 0.96 & 23 & 0.94 & 3.6 & 0.2 & 96.1 \\
\hline & Lys & 12.4 & 7.9 & 0.93 & 23 & 0.81 & 3.5 & 4.4 & 92.0 \\
\hline & Met & 3.9 & 8.3 & 0.94 & 11 & 0.67 & 15.9 & 5.7 & 78.5 \\
\hline & Phe & 9.4 & 7.3 & 0.93 & 17 & 0.82 & 4.4 & 3.3 & 92.3 \\
\hline & Thr & 7.7 & 6.3 & 0.95 & 25 & 0.82 & 1.7 & 3.2 & 95.1 \\
\hline & Val & 8.4 & 6.0 & 0.95 & 23 & 0.80 & 2.3 & 7.0 & 90.8 \\
\hline \multirow[t]{7}{*}{ CPM } & $\mathrm{CP}$ & 202.2 & 6.7 & 0.93 & 462 & 0.80 & 4.9 & 0.7 & 94.6 \\
\hline & MCP & 178.6 & 11.1 & 0.80 & 531 & 0.52 & 56.9 & 10.1 & 33.0 \\
\hline & RUP & 245.2 & 16.6 & 0.84 & 812 & 0.55 & 29.4 & 0.4 & 70.2 \\
\hline & Arg & 11.4 & 9.3 & 0.91 & 32 & 0.56 & 53.0 & 9.4 & 37.6 \\
\hline & His & 5.8 & 9.5 & 0.92 & 11 & 0.70 & 17.9 & 14.7 & 67.4 \\
\hline & Ile & 9.0 & 7.6 & 0.93 & 36 & 0.61 & 19.3 & 7.0 & 73.7 \\
\hline & Leu & 16.9 & 7.3 & 0.95 & 31 & 0.89 & 1.4 & 0.3 & 98.3 \\
\hline \multirow{9}{*}{ NRC } & Arg & 11.2 & 9.2 & 0.91 & 26 & 0.82 & 4.3 & 3.2 & 92.5 \\
\hline & His & 5.8 & 9.5 & 0.92 & 6 & 0.96 & 6.9 & 3.6 & 89.4 \\
\hline & Ile & 9.1 & 7.6 & 0.92 & 28 & 0.76 & 0.0 & 3.2 & 96.8 \\
\hline & Leu & 16.9 & 7.3 & 0.95 & 17 & 0.94 & 0.6 & 0.0 & 99.4 \\
\hline & Lys & 13.1 & 8.3 & 0.92 & 13 & 0.89 & 0.9 & 0.8 & 98.4 \\
\hline & Met & 3.8 & 8.1 & 0.94 & 6 & 0.86 & 0.1 & 1.4 & 98.6 \\
\hline & Phe & 11.4 & 8.8 & 0.92 & 23 & 0.83 & 1.5 & 0.6 & 97.9 \\
\hline & Thr & 8.2 & 6.7 & 0.94 & 27 & 0.79 & 0.8 & 1.6 & 97.6 \\
\hline & Val & 10.2 & 7.2 & 0.95 & 11 & 0.94 & 0.9 & 0.3 & 98.8 \\
\hline
\end{tabular}

${ }^{1} \mathrm{AC}=$ AminoCow AMTS $=$ Agricultural Modeling and Training Systems; CPM $=$ Cornell-Penn-Miner version of CNCPS; NRC $=$ National Research Council (2001); see text for details on the versions used.

${ }^{2} \mathrm{RMSPE}=$ root mean square prediction error; $\mathrm{RPE}=$ relative prediction error RMSPE as a percentage of the observed mean.

${ }^{3}$ Intercept.

${ }^{4} \mathrm{MSPE}=$ mean square prediction error with percentage due to mean, regression, and random disturbance biases.

${ }^{5}$ Microbial CP.

CPM predicted microbial CP to be $19 \%$ greater than was observed, AMTS was very precise (1\%), whereas $\mathrm{AC}$ and $\mathrm{NRC}$ underpredicted the flow of microbial CP but within an acceptable range. The decomposition of error revealed $36 \%$ mean bias as well as 19\% regression bias for the CPM prediction of microbial CP. In contrast, for corn-based diets, all models predicted more microbial CP than was observed, but within $5 \%$ except 
Table 4. Observed and predicted duodenal flows $(\mathrm{g} / \mathrm{d})$, and statistical adequacy of 4 programs ${ }^{1}$ for rations of grass-based diets $(\mathrm{n}=23)$

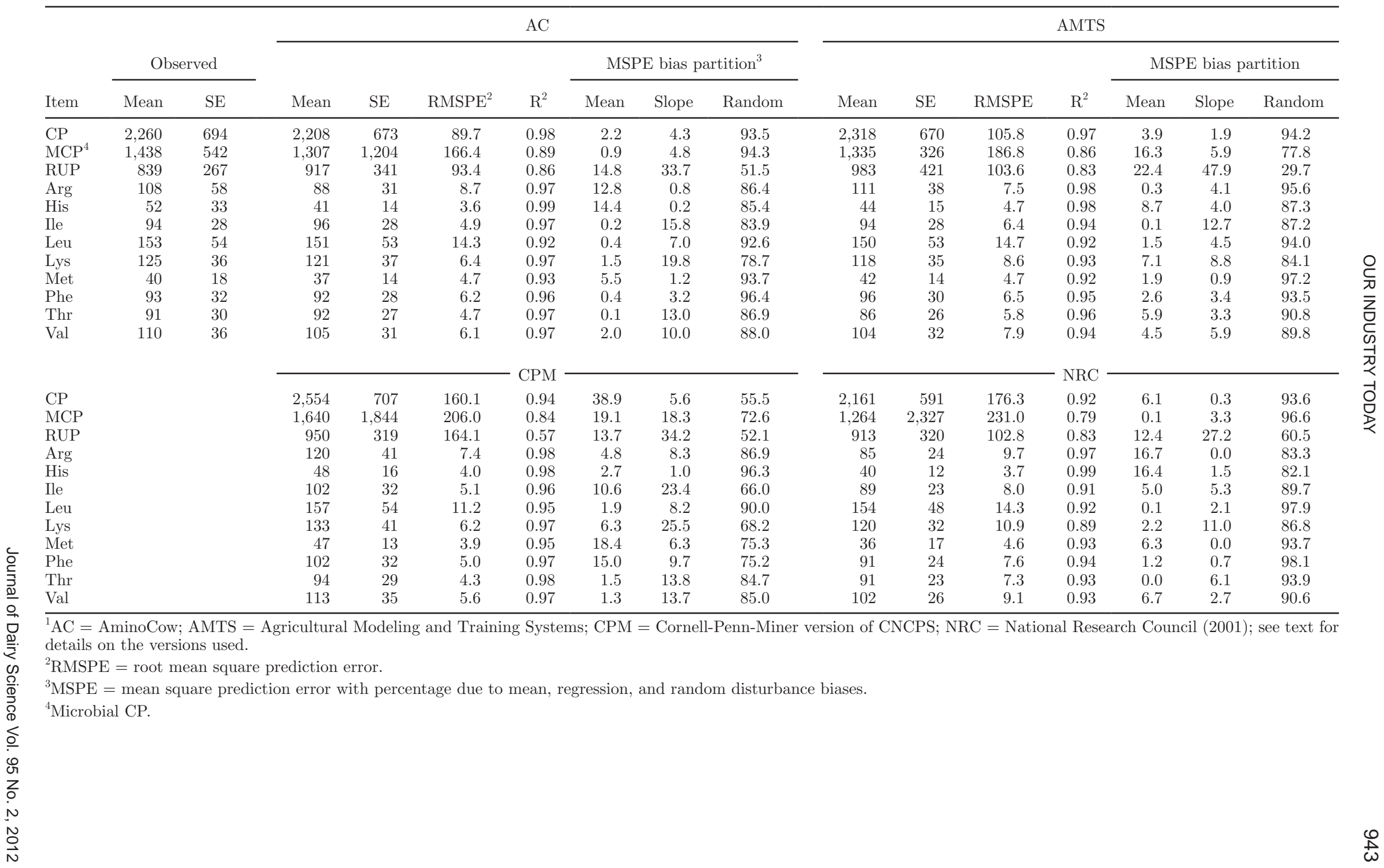


Table 5. Observed and predicted duodenal flows $(\mathrm{g} / \mathrm{d})$, and statistical adequacy of 4 programs $^{1}$ for rations of alfalfa-based diets $(\mathrm{n}=36)$

AC

\begin{tabular}{lrr}
\cline { 2 - 3 } Item & Mean & \\
\hline CP & 3,354 & 8 \\
MCP $^{4}$ & 1,742 & 3 \\
RUP & 1,622 & 7 \\
Arg & 132 & \\
His & 66 & \\
Ile & 133 \\
Leu & 258 \\
Lys & 180 \\
Met & 47 \\
Phe & 148 \\
Thr & 140 \\
Val & 156
\end{tabular}

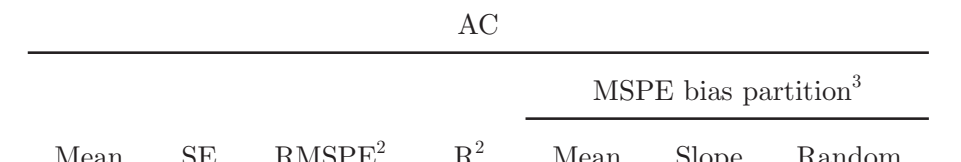

\begin{tabular}{|c|c|c|c|c|c|c|}
\hline \multirow[b]{2}{*}{ Mean } & \multirow[b]{2}{*}{ SE } & \multirow[b]{2}{*}{ RMSPE } & \multirow[b]{2}{*}{$\mathrm{R}^{2}$} & \multicolumn{3}{|c|}{ MSPE bias partition } \\
\hline & & & & Mean & Slope & Random \\
\hline
\end{tabular}

$\begin{array}{lll}3,231 & 562 & 190.3 \\ 1,874 & 400 & 151.2\end{array}$

0.95 Slope Random

$\begin{array}{lll}88.5 & 3,236 & 423 \\ 52.5 & 1,784 & 230\end{array}$

$\begin{array}{rrrr}0.95 & 5.1 & 6.5 & 88.5 \\ 0.77 & 11.1 & 36.4 & 52.5\end{array}$

$\begin{array}{llll}0.97 & 20.2 & 29.2 & 50.5\end{array}$

$\begin{array}{llll}0.94 & 0.0 & 1.2 & 98.8\end{array}$

$\begin{array}{llll}0.92 & 3.6 & 2.7 & 93.8 \\ 0.96 & 7.4 & 3.3 & 89.3\end{array}$

$\begin{array}{rrrr}0.96 & 7.4 & 3.3 & 89.3 \\ 0.97 & 13.1 & 4.9 & 82.0\end{array}$

$\begin{array}{lrrr}0.97 & 13.1 & 4.9 & 82.0\end{array}$

\begin{tabular}{|c|c|c|c|c|c|}
\hline 181 & 30 & 12.4 & 0.93 & 0.1 & 0.0 \\
\hline 52 & 9 & 3.2 & 0.93 & 15.7 & 2.8 \\
\hline 139 & 24 & 8.9 & 0.94 & 14.2 & 4.8 \\
\hline 138 & 23 & 7.4 & 0.95 & 0.9 & 3.3 \\
\hline
\end{tabular}

$\begin{array}{rrrrrrrr}48 & 181 & 30 & 12.4 & 0.93 & 0.1 & 0.0 & 99.9 \\ 13 & 52 & 9 & 3.2 & 0.93 & 15.7 & 2.8 & 81.5 \\ 38 & 139 & 24 & 8.9 & 0.94 & 14.2 & 4.8 & 81.1 \\ 35 & 138 & 23 & 7.4 & 0.95 & 0.9 & 3.3 & 95.8\end{array}$

$\begin{array}{rrrrrrrr}48 & 181 & 30 & 12.4 & 0.93 & 0.1 & 0.0 & 99.9 \\ 13 & 52 & 9 & 3.2 & 0.93 & 15.7 & 2.8 & 81.5 \\ 38 & 139 & 24 & 8.9 & 0.94 & 14.2 & 4.8 & 81.1 \\ 35 & 138 & 23 & 7.4 & 0.95 & 0.9 & 3.3 & 95.8\end{array}$

\begin{tabular}{|c|c|c|c|c|c|c|c|c|c|c|c|c|c|}
\hline 181 & 30 & 12.4 & 0.93 & 0.1 & 0.0 & 99.9 & 182 & 24 & 8.6 & 0.97 & 0.1 & 2.1 & 97.8 \\
\hline 52 & 9 & 3.2 & 0.93 & 15.7 & 2.8 & 81.5 & 55 & 8 & 2.7 & 0.95 & 33.9 & 0.5 & 65.6 \\
\hline 139 & 24 & 8.9 & 0.94 & 14.2 & 4.8 & 81.1 & 147 & 21 & 6.1 & 0.97 & 0.2 & 1.6 & 98.1 \\
\hline 138 & 23 & 7.4 & 0.95 & 0.9 & 3.3 & 95.8 & 132 & 17 & 6.3 & 0.96 & 7.1 & 1.2 & 91.7 \\
\hline 158 & 26 & 9.3 & 0.95 & 0.4 & 0.0 & 99.6 & 161 & 22 & 6.6 & 0.98 & 1.5 & 1.4 & 97.1 \\
\hline
\end{tabular}

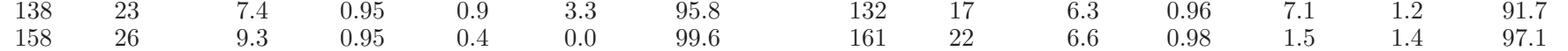

$1,452 \quad 266$

$\begin{array}{rr}1,452 & 266 \\ 168 & 20\end{array}$

$\begin{array}{rr}168 & 20 \\ 72 & 11\end{array}$

$\begin{array}{ll}140 & 17 \\ 234 & 38\end{array}$

$\begin{array}{lll}234 & 38 \\ 182 & 24\end{array}$

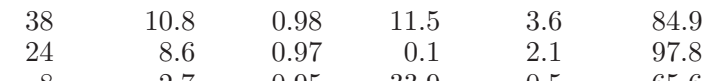

$\begin{array}{rr}55 & 8 \\ 147 & 21\end{array}$

$132 \quad 17$

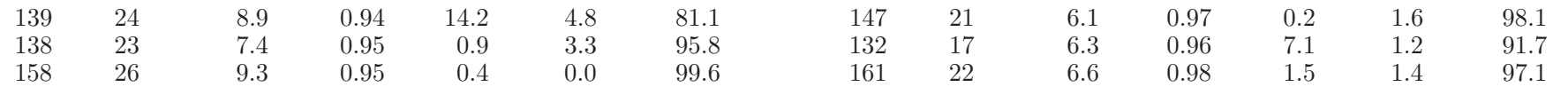

\begin{tabular}{lrr}
\cline { 2 - 2 } CP & 3,334 & 44 \\
MCP & 2,236 & 28 \\
RUP & 1,098 & 24 \\
Arg & 175 & 23 \\
His & 75 & 1 \\
Ile & 147 & 1 \\
Leu & 238 & 4 \\
Lys & 198 & 2 \\
Met & 63 & \\
Phe & 151 & 23 \\
Thr & 139 & 1 \\
Val & 169 & 2 \\
\hline
\end{tabular}

$\begin{array}{llll}\mathrm{CPM} & & & \\ & 0.94 & 5.9 & 94.0\end{array}$

\begin{tabular}{rr}
\hline 3,182 & 531 \\
1,774 & 218 \\
1,408 & 334 \\
126 & 20 \\
61 & 12 \\
130 & 21 \\
240 & 46 \\
178 & 27 \\
51 & 8 \\
134 & 22 \\
132 & 20 \\
150 & 24
\end{tabular}

$\begin{array}{rrr}531 & 157.0 & 0.96 \\ 218 & 160.6 & 0.74 \\ 334 & 118.4 & 0.97 \\ 20 & 7.7 & 0.94 \\ 12 & 5.0 & 0.92 \\ 21 & 7.3 & 0 \\ 46 & 12.5 & 0.97 \\ 27 & 11.6 & 0.94 \\ 8 & 3.4 & 0.92 \\ 22 & 12.9 & 0.87 \\ 20 & 7.4 & 0.95 \\ 24 & 8.3 & 0.96 \\ & & \end{array}$

\begin{tabular}{lrrl} 
NRC & & & \\
\cline { 2 - 4 } 0.96 & 10.7 & 16.9 & 72.4 \\
0.74 & 1.5 & 0.8 & 97.8 \\
0.97 & 16.4 & 21.1 & 62.5 \\
0.94 & 6.5 & 10.6 & 83.0 \\
0.92 & 16.4 & 6.2 & 77.4 \\
0.96 & 0.5 & 3.1 & 96.0 \\
0.97 & 9.3 & 10.2 & 80.5 \\
0.94 & 0.5 & 8.3 & 91.2 \\
0.92 & 13.6 & 0.0 & 86.4 \\
0.87 & 24.0 & 4.8 & 71.2 \\
0.95 & 7.0 & 0.2 & 92.9 \\
0.96 & 4.2 & 4.6 & 91.2
\end{tabular}

${ }^{1} \mathrm{AC}=$ AminoCow; AMTS = Agricultural Modeling and Training Systems; CPM = Cornell-Penn-Miner version of CNCPS; NRC = National Research Council (2001); see text for details on the versions used.

${ }^{2} \mathrm{RMSPE}=$ root mean square prediction error.

${ }^{3} \mathrm{MSPE}=$ mean square prediction error with percentage due to mean, regression, and random disturbance biases.

${ }^{4}$ Microbial CP. 
Table 6. Observed and predicted duodenal flows $(\mathrm{g} / \mathrm{d})$, and statistical adequacy of 4 programs ${ }^{1}$ for rations of corn silage-based diets $(\mathrm{n}=68)$

\begin{tabular}{|c|c|c|c|c|c|c|c|c|c|c|c|c|c|c|c|c|}
\hline \multirow[b]{3}{*}{ Item } & & & \multicolumn{7}{|c|}{$\mathrm{AC}$} & \multicolumn{7}{|c|}{ AMTS } \\
\hline & \multicolumn{2}{|c|}{ Observed } & \multirow[b]{2}{*}{ Mean } & \multirow[b]{2}{*}{$\mathrm{SE}$} & \multirow[b]{2}{*}{$\mathrm{RMSPE}^{2}$} & \multirow[b]{2}{*}{$\mathrm{R}^{2}$} & \multicolumn{3}{|c|}{ MSPE bias partition ${ }^{3}$} & \multirow[b]{2}{*}{ Mean } & \multirow[b]{2}{*}{$\mathrm{SE}$} & \multirow[b]{2}{*}{ RMSPE } & \multirow[b]{2}{*}{$\mathrm{R}^{2}$} & \multicolumn{3}{|c|}{ MSPE bias partition } \\
\hline & Mean & SE & & & & & Mean & Slope & Random & & & & & Mean & Slope & Random \\
\hline CP & 3,007 & 688 & 3,011 & 691 & 146.5 & 0.95 & 0.0 & 14.9 & 85.1 & 3,060 & 550 & 150.6 & 0.95 & 1.1 & 1.9 & 97.0 \\
\hline $\mathrm{MCP}^{4}$ & 1,524 & 404 & 1,543 & 513 & 153.0 & 0.85 & 0.1 & 47.4 & 52.4 & 1,676 & 292 & 98.6 & 0.94 & 20.2 & 1.5 & 78.4 \\
\hline RUP & 1,568 & 550 & 1,464 & 334 & 163.4 & 0.91 & 2.9 & 0.1 & 96.9 & 1,383 & 353 & 150.0 & 0.92 & 0.0 & 0.2 & 99.8 \\
\hline $\operatorname{Arg}$ & 122 & 35 & 128 & 33 & 12.3 & 0.87 & 55.1 & 14.4 & 80.5 & 154 & 36 & 12.3 & 0.87 & 51.6 & 10.3 & 38.1 \\
\hline His & 59 & 16 & 61 & 16 & 5.8 & 0.86 & 2.2 & 12.8 & 85.0 & 67 & 16 & 5.9 & 0.85 & 28.6 & 10.8 & 60.5 \\
\hline Ile & 125 & 33 & 129 & 33 & 9.3 & 0.92 & 1.3 & 21.4 & 77.3 & 126 & 24 & 9.7 & 0.91 & 0.2 & 3.1 & 96.7 \\
\hline Leu & 250 & 66 & 231 & 55 & 18.6 & 0.92 & 16.8 & 0.5 & 82.8 & 226 & 49 & 17.8 & 0.92 & 28.3 & 1.4 & 70.2 \\
\hline Lys & 157 & 47 & 162 & 45 & 12.0 & 0.93 & 2.3 & 12.5 & 85.2 & 165 & 38 & 13.3 & 0.92 & 6.4 & 1.5 & 92.1 \\
\hline Met & 49 & 15 & 49 & 12 & 3.4 & 0.94 & 0.5 & 6.1 & 93.5 & 53 & 10 & 4.0 & 0.92 & 10.5 & 4.3 & 85.2 \\
\hline Phe & 131 & 34 & 132 & 30 & 10.5 & 0.90 & 0.3 & 4.3 & 95.5 & 136 & 27 & 10.8 & 0.89 & 4.9 & 0.3 & 94.8 \\
\hline Thr & 125 & 30 & 127 & 29 & 7.5 & 0.94 & 0.3 & 10.9 & 88.8 & 121 & 24 & 7.7 & 0.93 & 3.8 & 1.0 & 95.2 \\
\hline Val & 147 & 45 & 148 & 33 & 10.3 & 0.94 & 0.2 & 0.8 & 99.0 & 142 & 28 & 11.1 & 0.94 & 0.3 & 0.1 & 99.5 \\
\hline $\mathrm{CP}$ & & & 3,178 & 543 & 190.5 & 0.92 & 11.4 & 0.9 & 87.7 & 3,049 & 616 & 171.0 & 0.94 & 1.0 & 3.0 & 96.1 \\
\hline MCP & & & 2,022 & 369 & 100.3 & 0.94 & 70.2 & 3.2 & 26.6 & 1,539 & 340 & 111.9 & 0.92 & 0.2 & 15.2 & 84.6 \\
\hline RUP & & & 1,182 & 301 & 200.1 & 0.86 & 36.3 & 1.9 & 61.8 & 1,517 & 384 & 176.9 & 0.89 & 0.0 & 0.3 & 99.7 \\
\hline Arg & & & 161 & 35 & 13.0 & 0.85 & 64.4 & 6.7 & 28.9 & 120 & 25 & 12.6 & 0.86 & 0.4 & 0.9 & 98.7 \\
\hline His & & & 70 & 17 & 6.6 & 0.82 & 41.5 & 13.0 & 45.5 & 58 & 13 & 6.5 & 0.82 & 0.5 & 4.2 & 95.3 \\
\hline Ile & & & 134 & 26 & 10.6 & 0.89 & 10.4 & 2.2 & 87.3 & 123 & 24 & 10.3 & 0.90 & 1.1 & 3.4 & 93.5 \\
\hline Leu & & & 229 & 51 & 20.9 & 0.90 & 22.5 & 0.6 & 76.8 & 239 & 51 & 20.5 & 0.90 & $\begin{array}{l}1.1 \\
5.9\end{array}$ & $\begin{array}{l}0.4 \\
0.1\end{array}$ & 94.0 \\
\hline Lys & & & 176 & 40 & 15.4 & 0.89 & 28.5 & 1.7 & 69.8 & 162 & 35 & 13.3 & 0.92 & 2.6 & 0.0 & 97.4 \\
\hline Met & & & 59 & 11 & 4.3 & 0.91 & 37.8 & 2.9 & 59.3 & 48 & 10 & 3.8 & 0.93 & 0.8 & 0.9 & 98.3 \\
\hline Phe & & & 141 & 28 & 12.6 & 0.85 & 17.4 & 1.1 & 81.5 & 131 & 27 & 12.0 & 0.87 & 0.0 & 0.3 & 99.7 \\
\hline Thr & & & 128 & 25 & 9.2 & 0.90 & 1.2 & 0.8 & 98.0 & 123 & 24 & 8.2 & 0.92 & 1.1 & 0.8 & 98.2 \\
\hline Val & & & 156 & 32 & 12.0 & 0.93 & 7.9 & 0.0 & 92.1 & 142 & 28 & 11.6 & 0.93 & 2.5 & 1.2 & 96.3 \\
\hline \multicolumn{17}{|c|}{$\begin{array}{l}{ }^{1} \mathrm{AC}=\text { AminoCow; AMTS }=\text { Agricultural Modeling and Training Systems; CPM = Cornell-Penn-Miner version of CNCPS; NRC }=\text { National Research Council }(2001) ; \text { see text } \mathrm{f} \\
\text { details on the versions used. }\end{array}$} \\
\hline \multirow{3}{*}{\multicolumn{17}{|c|}{$\begin{array}{l}{ }^{2} \mathrm{RMSPE}=\text { root mean squar } \\
{ }^{3} \mathrm{MSPE}=\text { mean square pred } \\
{ }^{4} \mathrm{Microbial} \mathrm{CP} \text {. }\end{array}$}} \\
\hline & & & & & & & & & & & & & & & & \\
\hline & & & & & & & & & & & & & & & & \\
\hline & & & & & & & & & & & & & & & & \\
\hline & & & & & & & & & & & & & & & & \\
\hline & & & & & & & & & & & & & & & & \\
\hline & & & & & & & & & & & & & & & & \\
\hline
\end{tabular}


for the CPM model, which predicted excessively high (31\%). Error decomposition suggested that this was due largely to mean biases of 67 and $32 \%$, respectively.

For both sources of dietary carbohydrate, the RUP fraction was systematically underpredicted: within acceptable limits for the non-corn-based diets, except for the CPM model, which underpredicted it by $20 \%$, and by $10 \%$ for the corn diets, except for the CPM model, in which the overprediction of microbial $\mathrm{CP}$ resulted in underprediction of the RUP flow by $24 \%$. The error was mainly associated with a mean bias of 25 and $32 \%$ for non-corn-based and corn-based diets, respectively. For both diet types, AMTS generally displayed the lowest RMSPE and CPM the highest for all protein fractions.

Individual $\boldsymbol{A} \boldsymbol{A}$. Predictions of EAA flow to the duodenum were more variable for non-corn-based diets compared with corn-based diets (Tables 7 and 8). For the non-corn-based diets, Arg flow was overpredicted outside of an acceptable limit by AMTS and CPM but underpredicted within accurate range for the other 2 models. Histidine was underpredicted by $16 \%$ by $\mathrm{AC}$ and $22 \%$ by NRC. This was due to a $21 \%$ mean bias for $\mathrm{AC}$ and a $28 \%$ mean bias for NRC. Isoleucine was overpredicted by all models, with AC (17\%), AMTS $(22 \%)$, and CPM (28\%) predicting unacceptably high. Only NRC predicted Ile in a useful range for non-cornbased diets. This error decomposition suggested strong mean bias for all models for prediction of Ile flow to the duodenum, being $60,51,50$, and $65 \%$ for AC, AMTS, CPM, and NRC, respectively. Leucine, Lys, Met, and Val were predicted within acceptable limits by AC, AMTS, and NRC, except for Met with AMTS, which was overpredicted by $29 \%$. Flows of these AA were overpredicted by more than $15 \%$ by CPM, with Met being overpredicted by $43 \%$ on non-corn-based diets (Tables 7 and 8). Error associated with Met flow from non-corn-based diets consisted of $52 \%$ mean bias and $11 \%$ regression bias for the CPM model and $29 \%$ mean bias and 19\% regression bias for the AMTS model. Prediction of the flows of Leu, Lys, and Val by the CPM model displayed mean bias $(25,19$, and $38 \%$, respectively) and regression bias $(21,26$, and $29 \%$, respectively).

On the corn-based diets, Arg was overpredicted by $25 \%$ by AMTS and $32 \%$ for CPM. This error was 49 and $67 \%$ mean bias, respectively (Tables 7 and 8). Although all models underpredicted Leu flow and overpredicted Lys flow, these were all within $10 \%$ of mean observed values. Predicted flows of other AA were all accurate with the exceptions of His and Met flow by CPM, which were overpredicted by 17 and $21 \%$, respectively. Apportionment of error for these AA in CPM indicated that Met overprediction was mainly due to mean bias, but that His was due to a mixture of mean and regression bias.

For non-corn-based diets, although CPM did not predict the mean accurately, it did predict precisely as evidenced by the lowest RMSPE. The NRC model, which was the most accurate for predicting mean flows, had the highest RMSPE overall. Overall, with noncorn-based diets, the ratio of predicted:observed duodenal flows of EAA was always greater than the ratio of predicted:observed CP flows, whereas for corn-based diets, the prediction of total EAA followed more closely the prediction of $\mathrm{CP}$ flow.

\section{Effect of RUP}

Protein Fractions. For diets with no source of proteins considered to be high in RUP (Tables 9 and 10), CP flow was very accurately estimated by the 4 models. Microbial CP flow was estimated within $5 \%$ by AC, AMTS, and NRC, whereas CPM overestimated microbial CP flow by $26 \%$. All models underestimated mean RUP flow but, with the exception of CPM (27\%), they were underestimated within acceptable limits. The CPM underprediction was mainly due to mean bias of $35 \%$. In fact, all models displayed more mean bias for predictions of RUP than would be desirable for the low RUP diets (Tables 9 and 10). The predictions of the protein fraction flows were similar for rations with RUP added as for the non-RUP rations. The AC, AMTS, and NRC models predicted both microbial $\mathrm{CP}$ and RUP within $5 \%$ of observed, whereas CPM overpredicted microbial CP (28\%) and underpredicted RUP (22\%).

Individual AA. All EAA of low RUP diets were predicted by AC, AMTS, and NRC within $10 \%$ of observed mean, except Arg and Met, which were overpredicted by 20 and $11 \%$, respectively by AMTS. The CPM model overpredicted the flow of all EAA except Leu and Thr, but within acceptable limits except for Arg and Met, which were overpredicted by 26 and $24 \%$, respectively, in low RUP diets. Error for Arg for both AMTS and CPM in these diets was due to a mix of mean bias and regression bias, whereas the Met error for CPM was due mainly to mean bias (Tables 9 and 10). For diets where RUP was added, EAA flows were predicted accurately with AC and NRC models. The AMTS model, on average, predicted greater flows, with His, Ile, and Met being acceptable and Arg, which was predicted to be $27 \%$ greater than observed with $47 \%$ mean bias (Tables 9 and 10). The CPM model overpredicted Arg (34\%), His (16\%), Ile (17\%), and Met (24\%). Except for His, which was a mix of mean and regression bias, all other errors were attributable to mean bias (Tables 9 and 10). When diets were evalu- 
Table 7. Observed and predicted duodenal flows $(\mathrm{g} / \mathrm{d})$, and statistical adequacy of 4 programs ${ }^{1}$ for rations different in source of NFC: non-corn-based diets $(\mathrm{n}=43)$

\begin{tabular}{|c|c|c|c|c|c|c|c|c|c|c|c|c|c|c|c|c|}
\hline \multirow[b]{3}{*}{ Item } & & & \multicolumn{7}{|c|}{$\mathrm{AC}$} & \multicolumn{7}{|c|}{ AMTS } \\
\hline & \multicolumn{2}{|c|}{ Observed } & \multirow[b]{2}{*}{ Mean } & \multirow[b]{2}{*}{$\mathrm{SE}$} & \multirow[b]{2}{*}{$\mathrm{RMSPE}^{2}$} & \multirow[b]{2}{*}{$\mathrm{R}^{2}$} & \multicolumn{3}{|c|}{ MSPE bias partition ${ }^{3}$} & \multirow[b]{2}{*}{ Mean } & \multirow[b]{2}{*}{ SE } & \multirow[b]{2}{*}{ RMSPE } & \multirow[b]{2}{*}{$\mathrm{R}^{2}$} & \multicolumn{3}{|c|}{ MSPE bias partition } \\
\hline & Mean & $\mathrm{SE}$ & & & & & Mean & Slope & Random & & & & & Mean & Slope & Random \\
\hline $\mathrm{CP}$ & 2,673 & 793 & 2,471 & 800 & 153.1 & 0.96 & 19.1 & 10.4 & 70.5 & 2,674 & 779 & 172.7 & 0.95 & 0.0 & 5.0 & 95.0 \\
\hline $\mathrm{MCP}^{4}$ & 1,585 & 457 & 1,464 & 475 & 236.3 & 0.71 & 8.8 & 35.0 & 56.2 & 1,606 & 416 & 245.6 & 0.69 & 0.3 & 18.8 & 80.9 \\
\hline RUP & 1,177 & 511 & 1,059 & 353 & 236.5 & 0.76 & 14.2 & 4.3 & 81.5 & 1,068 & 436 & 213.0 & 0.81 & 2.6 & 0.4 & 97.0 \\
\hline Arg & 106 & 46 & 99 & 30 & 9.6 & 0.95 & 10.3 & 1.1 & 88.6 & 130 & 42 & 10.0 & 0.95 & 20.7 & 15.0 & 64.3 \\
\hline His & 57 & 27 & 48 & 16 & 5.4 & 0.96 & 21.4 & 0.6 & 78.0 & 56 & 22 & 6.1 & 0.95 & 0.6 & 8.4 & 91.0 \\
\hline Ile & 92 & 33 & 108 & 33 & 6.6 & 0.96 & 60.0 & 0.2 & 39.8 & 112 & 36 & 6.9 & 0.95 & 51.1 & 0.2 & 48.7 \\
\hline Leu & 160 & 63 & 178 & 65 & 14.9 & 0.94 & 7.1 & 22.7 & 70.2 & 184 & 70 & 14.8 & 0.94 & 16.3 & 27.2 & 56.5 \\
\hline Lys & 131 & 42 & 138 & 43 & 9.8 & 0.94 & 2.3 & 31.1 & 66.6 & 142 & 22 & 11.2 & 0.92 & 10.6 & 34.6 & 54.8 \\
\hline Met & 37 & 17 & 40 & 13 & 3.9 & 0.94 & 2.5 & 16.1 & 81.4 & 48 & 14 & 4.0 & 0.94 & 28.8 & 19.2 & 52.0 \\
\hline Phe & 107 & 39 & 108 & 36 & 8.7 & 0.95 & 0.6 & 3.9 & 95.5 & 118 & 42 & 8.8 & 0.94 & 20.4 & 15.5 & 64.1 \\
\hline Thr & 100 & 30 & 106 & 32 & 8.1 & 0.92 & 5.1 & 28.6 & 66.3 & 104 & 34 & 8.6 & 0.91 & 5.5 & 30.0 & 64.5 \\
\hline Val & 112 & 40 & 122 & 39 & 7.4 & 0.96 & 4.0 & 31.8 & 64.2 & 129 & 46 & 8.1 & 0.95 & 12.0 & 41.2 & 46.8 \\
\hline $\mathrm{CP}$ & & & 2,781 & 713 & 186.2 & 0.94 & 3.3 & 1.4 & 95.3 & 2,440 & 675 & 201.9 & 0.93 & 25.5 & 0.2 & 74.3 \\
\hline MCP & & & 1,886 & 495 & 246.9 & 0.69 & 36.2 & 18.9 & 44.9 & 1,420 & 333 & 235.1 & 0.72 & 19.9 & 5.2 & 74.9 \\
\hline RUP & & & 947 & 293 & 318.0 & 0.58 & 25.2 & 4.7 & 70.1 & 1,087 & 383 & 258.5 & 0.72 & 7.5 & 0.3 & 92.2 \\
\hline Arg & & & 137 & 43 & 9.3 & 0.96 & 33.8 & 10.5 & 55.7 & 94 & 26 & 10.9 & 0.94 & 17.1 & 0.3 & 82.6 \\
\hline His & & & 59 & 22 & 5.8 & 0.95 & 17.0 & 24.9 & 58.1 & 45 & 14 & 5.6 & 0.95 & 28.2 & 0.2 & 71.6 \\
\hline Ile & & & 118 & 35 & 6.4 & 0.96 & 49.8 & 1.1 & 49.1 & 101 & 25 & 8.0 & 0.94 & 64.6 & 3.0 & 32.4 \\
\hline Leu & & & 188 & 68 & 13.4 & 0.95 & 24.8 & 18.7 & 56.5 & 182 & 62 & 14.5 & 0.94 & 12.2 & 18.0 & 69.8 \\
\hline Lys & & & 154 & 47 & 9.5 & 0.94 & 37.8 & 21.3 & 40.9 & 135 & 35 & 11.9 & 0.91 & 1.8 & 14.2 & 84.0 \\
\hline Met & & & 53 & 16 & 3.6 & 0.95 & 51.6 & 11.2 & 37.2 & 40 & 11 & 3.8 & 0.94 & 2.0 & 7.6 & 90.4 \\
\hline Phe & & & 122 & 41 & 8.6 & 0.95 & 41.7 & 6.5 & 51.8 & 105 & 30 & 10.2 & 0.93 & 3.8 & 0.5 & 95.7 \\
\hline Thr & & & 110 & 34 & 8.0 & 0.92 & 24.4 & 20.8 & 54.8 & 102 & 26 & 8.7 & 0.91 & 1.2 & 9.7 & 89.1 \\
\hline Val & & & 135 & 45 & 7.0 & 0.96 & 26.0 & 28.7 & 45.3 & 117 & 31 & 8.7 & 0.95 & 1.1 & 16.7 & 82.2 \\
\hline $\begin{array}{l}{ }^{1} \mathrm{AC}= \\
\text { details } \\
{ }^{2} \mathrm{RMSP} \\
{ }^{3} \mathrm{MSPE} \\
{ }^{4} \mathrm{Microl}\end{array}$ & $\begin{array}{l}\text { inoCow } \\
\text { the versi } \\
=\text { root } m \\
\text { mean sq } \\
\text { CP. }\end{array}$ & $\begin{array}{l}\text { AMT } \\
\text { ons us } \\
\text { ean sq } \\
\text { tare p }\end{array}$ & $\begin{array}{l}\text { gricultu } \\
\text { predictio } \\
\text { ion erro }\end{array}$ & $\begin{array}{l}\text { Mod } \\
\text { error. } \\
\text { with p }\end{array}$ & ing and Tra & ing Sys & ms; CP & $=$ Corn & -Penn-Min & sion of & TCPS; & $\mathrm{RC}=\mathrm{Nat}$ & nal Res & rech Cor & cil (2001 & see text $f$ \\
\hline
\end{tabular}


Table 8. Observed and predicted duodenal flows $(\mathrm{g} / \mathrm{d})$, and statistical adequacy of 4 programs ${ }^{1}$ for rations different in source of NFC: corn-based diets $(\mathrm{n}=107)$

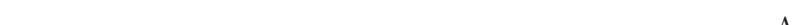

$\mathrm{AC}$

AMTS

\begin{tabular}{|c|c|c|c|c|c|c|c|c|c|c|c|c|c|c|c|c|}
\hline Item & Mean & $\mathrm{SE}$ & Mean & SE & $\mathrm{RMSPE}^{2}$ & $\mathrm{R}^{2}$ & Mean & Slope & Random & Mean & $\mathrm{SE}$ & RMSPE & $\mathrm{R}^{2}$ & Mean & Slope & Random \\
\hline $\mathrm{CP}$ & 3,162 & 761 & 3,146 & 682 & 156.6 & 0.96 & 0.1 & 6.6 & 93.3 & 3,165 & 526 & 146.7 & 0.96 & 0.0 & 0.0 & 100.0 \\
\hline $\mathrm{MCP}^{4}$ & 1,615 & 393 & 1,673 & 504 & 151.3 & 0.85 & 1.4 & 45.6 & 53.0 & 1,701 & 263 & 118.7 & 0.91 & 6.9 & 2.1 & 91.0 \\
\hline RUP & 1,599 & 623 & 1,476 & 331 & 148.0 & 0.94 & 4.3 & 1.2 & 94.5 & 1,463 & 347 & 146.0 & 0.94 & 4.7 & 1.9 & 93.4 \\
\hline Arg & 128 & 34 & 132 & 30 & 10.7 & 0.90 & 1.8 & 16.0 & 82.2 & 160 & 32 & 10.8 & 0.89 & 49.3 & 10.2 & 40.5 \\
\hline His & 62 & 17 & 64 & 16 & 5.5 & 0.89 & 1.6 & 13.8 & 84.6 & 70 & 16 & 5.3 & 0.90 & 24.9 & 9.7 & 65.4 \\
\hline Ile & 130 & 31 & 136 & 32 & 8.5 & 0.92 & 2.6 & 24.1 & 73.3 & 132 & 230 & 8.5 & 0.91 & 0.3 & 5.6 & 94.1 \\
\hline Leu & 260 & 67 & 238 & 56 & 17.9 & 0.93 & 17.8 & 1.8 & 80.4 & 234 & 49 & 15.4 & 0.95 & 25.2 & 0.0 & 74.8 \\
\hline Lys & 169 & 47 & 172 & 43 & 13.4 & 0.92 & 0.7 & 10.7 & 88.6 & 172 & 35 & 12.7 & 0.92 & 1.2 & 0.8 & 98.0 \\
\hline Met & 51 & 14 & 51 & 11 & 3.5 & 0.93 & 0.0 & 8.9 & 91.1 & 55 & 10 & 3.7 & 0.92 & 9.6 & 3.8 & 86.6 \\
\hline Phe & 138 & 34 & 137 & 30 & 9.6 & 0.92 & 0.2 & 7.4 & 92.4 & 141 & 26 & 9.1 & 0.93 & 1.3 & 2.3 & 96.4 \\
\hline Thr & 134 & 30 & 133 & 29 & 7.4 & 0.94 & 0.1 & 14.3 & 85.6 & 126 & 22 & 7.2 & 0.94 & 8.7 & 2.5 & 88.8 \\
\hline Val & 154 & 42 & 155 & 33 & 10.4 & 0.94 & 0.0 & 4.1 & 95.9 & 155 & 29 & 10.4 & 0.94 & 0.1 & 1.0 & 98.9 \\
\hline $\mathrm{CP}$ & & & 3,303 & 542 & 184.2 & 0.94 & 6.0 & 0.2 & 93.8 & 3,161 & 612 & 159.0 & 0.96 & 0.0 & 0.3 & 99.7 \\
\hline MCP & & & 2,115 & 365 & 126.2 & 0.89 & 67.1 & 5.2 & 27.7 & 1,640 & 325 & 129.4 & 0.89 & 0.5 & 11.5 & 88.0 \\
\hline RUP & & & 1,209 & 292 & 194.0 & 0.90 & 31.7 & 0.5 & 67.8 & 1,528 & 167 & 165.0 & 0.93 & 1.2 & 0.9 & 97.9 \\
\hline Arg & & & 169 & 33 & 11.2 & 0.89 & 62.3 & 7.8 & 29.9 & 124 & 25 & 10.8 & 0.89 & 1.6 & 3.5 & 94.9 \\
\hline His & & & 73 & 18 & 5.7 & 0.88 & 38.7 & 13.4 & 47.9 & 61 & 14 & 5.7 & 0.88 & 0.8 & 3.5 & 95.7 \\
\hline Ile & & & 141 & 25 & 9.5 & 0.90 & 12.7 & 7.0 & 80.3 & 127 & 24 & 9.4 & 0.91 & 1.3 & 5.7 & 93.0 \\
\hline Leu & & & 238 & 53 & 17.6 & 0.93 & 17.8 & 0.7 & 81.5 & 245 & 53 & 17.8 & 0.93 & 10.6 & 0.1 & 89.3 \\
\hline Lys & & & 187 & 39 & 14.8 & 0.90 & 22.2 & 3.5 & 74.3 & 170 & 35 & 13.3 & 0.92 & 0.3 & 0.1 & 99.6 \\
\hline Met & & & 62 & 11 & 3.9 & 0.91 & 45.4 & 4.3 & 50.3 & 50 & 9 & 3.7 & 0.92 & 0.6 & 2.2 & 97.2 \\
\hline Phe & & & 147 & 28 & 10.2 & 0.90 & 10.6 & 5.6 & 83.8 & 135 & 27 & 11.7 & 0.88 & 1.8 & 2.4 & 95.8 \\
\hline Thr & & & 134 & 24 & 8.2 & 0.92 & 0.0 & 5.9 & 94.1 & 129 & 24 & 7.8 & 0.93 & 4.0 & 3.9 & 92.1 \\
\hline Val & & & 164 & 32 & 10.9 & 0.93 & 7.8 & 3.6 & 88.6 & 147 & 29 & 10.8 & 0.93 & 4.8 & 0.0 & 95.2 \\
\hline
\end{tabular}

${ }^{1} \mathrm{AC}=$ AminoCow; AMTS = Agricultural Modeling and Training Systems; CPM = Cornell-Penn-Miner version of CNCPS; NRC = National Research Council (2001); see text for details on the versions used.

${ }^{2} \mathrm{RMSPE}=$ root mean square prediction error.

${ }^{3} \mathrm{MSPE}=$ mean square prediction error with percentage due to mean, regression, and random disturbance biases.

${ }^{4}$ Microbial CP. 
Table 9. Observed and predicted duodenal flows $(\mathrm{g} / \mathrm{d})$, and statistical adequacy of 4 programs ${ }^{1}$ for rations without added RUP sources $(\mathrm{n}=60)$

\begin{tabular}{|c|c|c|c|c|c|c|c|c|c|c|c|c|c|c|c|c|}
\hline \multirow[b]{3}{*}{ Item } & & & \multicolumn{7}{|c|}{$\mathrm{AC}$} & \multicolumn{7}{|c|}{ AMTS } \\
\hline & \multicolumn{2}{|c|}{ Observed } & \multirow[b]{2}{*}{ Mean } & \multirow[b]{2}{*}{$\mathrm{SE}$} & \multirow[b]{2}{*}{$\mathrm{RMSPE}^{2}$} & \multirow[b]{2}{*}{$\mathrm{R}^{2}$} & \multicolumn{3}{|c|}{ MSPE bias partition ${ }^{3}$} & \multirow[b]{2}{*}{ Mean } & \multirow[b]{2}{*}{$\mathrm{SE}$} & \multirow[b]{2}{*}{ RMSPE } & \multirow[b]{2}{*}{$\mathrm{R}^{2}$} & \multicolumn{3}{|c|}{ MSPE bias partition } \\
\hline & Mean & $\mathrm{SE}$ & & & & & Mean & Slope & Random & & & & & Mean & Slope & Random \\
\hline $\mathrm{CP}$ & 3,002 & 828 & 2,890 & 863 & 128.5 & 0.98 & 4.5 & 13.0 & 82.5 & 2,918 & 648 & 117.5 & 0.98 & 3.7 & 2.1 & 94.2 \\
\hline $\mathrm{MCP}^{4}$ & 1,671 & 377 & 1.731 & 532 & 148.6 & 0.84 & 1.3 & 56.6 & 42.1 & 1,715 & 295 & 144.3 & 0.84 & 2.2 & 5.4 & 92.4 \\
\hline RUP & 1,422 & 616 & 1,209 & 319 & 103.2 & 0.97 & 23.0 & 18.2 & 58.8 & 1,204 & 200 & 75.5 & 0.98 & 14.7 & 13.7 & 71.6 \\
\hline $\mathrm{Arg}$ & 123 & 40 & 119 & 36 & 6.8 & 0.97 & 1.3 & 13.8 & 84.9 & 147 & 38 & 6.5 & 0.97 & 29.4 & 13.2 & 57.4 \\
\hline His & 59 & 20 & 55 & 17 & 3.0 & 0.98 & 4.4 & 10.8 & 84.8 & 61 & 17 & 2.7 & 0.98 & 2.0 & 10.5 & 87.5 \\
\hline Ile & 125 & 35 & 128 & 37 & 6.4 & 0.96 & 0.9 & 21.0 & 78.1 & 123 & 29 & 6.1 & 0.97 & 0.5 & 4.0 & 95.5 \\
\hline Leu & 222 & 74 & 205 & 63 & 12.3 & 0.97 & 15.5 & 0.1 & 84.4 & 201 & 54 & 10.0 & 0.98 & 20.5 & 3.1 & 76.4 \\
\hline Lys & 162 & 45 & 161 & 48 & 9.0 & 0.96 & 0.3 & 19.4 & 80.3 & 161 & 38 & 9.4 & 0.95 & 0.3 & 2.7 & 97.0 \\
\hline Met & 45 & 14 & 46 & 14 & 2.8 & 0.96 & 0.8 & 22.2 & 77.0 & 50 & 10 & 2.1 & 0.97 & 16.4 & 3.8 & 79.8 \\
\hline Phe & 127 & 38 & 123 & 37 & 6.3 & 0.97 & 4.9 & 5.5 & 89.6 & 126 & 32 & 5.8 & 0.96 & 0.4 & 0.0 & 99.6 \\
\hline Thr & 125 & 34 & 123 & 35 & 5.5 & 0.97 & 0.5 & 17.9 & 81.6 & 117 & 28 & 5.4 & 0.97 & 11.1 & 2.0 & 86.9 \\
\hline Val & 140 & 43 & 140 & 40 & 6.2 & 0.98 & 0.1 & 8.4 & 91.5 & 138 & 33 & 6.4 & 0.98 & 0.4 & 0.5 & 99.1 \\
\hline $\mathrm{CP}$ & & & 3,081 & 660 & 184.7 & 0.95 & 2.9 & 0.3 & 96.8 & 2,841 & 786 & 116.4 & 0.98 & 13.7 & 2.0 & 84.3 \\
\hline MCP & & & 2,107 & 441 & 159.7 & 0.81 & 56.5 & 15.2 & 28.3 & 1,627 & 357 & 147.3 & 0.84 & 1.5 & 20.3 & 78.2 \\
\hline RUP & & & 1,033 & 262 & 179.1 & 0.91 & 34.8 & 0.4 & 64.8 & 1,277 & 419 & 86.6 & 0.98 & 14.5 & 5.9 & 79.6 \\
\hline $\mathrm{Arg}$ & & & 155 & 41 & 6.7 & 0.97 & 43.4 & 12.2 & 44.4 & 113 & 33 & 6.4 & 0.97 & 8.3 & 7.3 & 84.4 \\
\hline His & & & 64 & 17 & 3.2 & 0.97 & 8.8 & 10.1 & 81.1 & 53 & 16 & 3.0 & 0.98 & 11.6 & 5.7 & 82.7 \\
\hline Ile & & & 131 & 32 & 6.9 & 0.96 & 6.4 & 6.1 & 87.5 & 118 & 31 & 6.2 & 0.97 & 7.0 & 3.7 & 89.3 \\
\hline Leu & & & 205 & 55 & 11.3 & 0.98 & 15.7 & 3.6 & 80.7 & 209 & 63 & 10.1 & 0.98 & 12.4 & 0.6 & 87.0 \\
\hline Lys & & & 174 & 43 & 12.3 & 0.92 & 12.5 & 7.7 & 79.8 & 158 & 41 & 10.2 & 0.94 & 2.3 & 5.7 & 92.0 \\
\hline Met & & & 56 & 13 & 2.6 & 0.96 & 50.3 & 7.8 & 41.9 & 45 & 12 & 2.6 & 0.96 & 0.1 & 12.6 & 87.3 \\
\hline Phe & & & 131 & 33 & 6.5 & 0.97 & 3.4 & 0.1 & 96.5 & 120 & 34 & 6.0 & 0.97 & 13.8 & 0.2 & 86.0 \\
\hline Thr & & & 124 & 31 & 6.1 & 0.96 & 0.2 & 6.2 & 93.6 & 118 & 31 & 5.7 & 0.97 & 7.7 & 5.4 & 86.9 \\
\hline Val & & & 146 & 36 & 7.2 & 0.97 & 4.2 & 1.2 & 94.6 & 133 & 34 & 6.4 & 0.98 & 7.9 & 0.1 & 92.0 \\
\hline $\begin{array}{l}{ }^{1} \mathrm{AC}= \\
\text { details } \\
{ }^{2} \mathrm{RMSP} \\
{ }^{3} \mathrm{MSPE} \\
{ }^{4} \mathrm{Microl}\end{array}$ & $\begin{array}{l}\text { minoCow; } \\
\mathrm{n} \text { the versi } \\
=\text { root } \mathrm{m} \\
=\text { mean } \mathrm{sq} \\
\text { al } \mathrm{CP} \text {. }\end{array}$ & $\begin{array}{l}\text { AMTS } \\
\text { is use } \\
\text { in squ } \\
\text { hre pre }\end{array}$ & $\begin{array}{l}\text { gricultur } \\
\text { rediction } \\
\text { n error }\end{array}$ & $\begin{array}{l}\text { Mode } \\
\text { rror. } \\
\text { ith pe }\end{array}$ & g and Trai & gg Syst & ns; CPN & $=$ Corne & Penn-Min & sion of $\mathrm{C}$ & CPS; & $\mathrm{RC}=\mathrm{Nat}$ & tal Rese & irch Cou & il (2001 & see text $\mathrm{f}$ \\
\hline
\end{tabular}


Table 10. Observed and predicted duodenal flows $(\mathrm{g} / \mathrm{d})$, and statistical adequacy of 4 programs ${ }^{1}$ for rations with added RUP sources $(\mathrm{n}=94)$

\begin{tabular}{|c|c|c|c|c|c|c|c|c|c|c|c|c|c|c|c|c|}
\hline \multirow[b]{3}{*}{ Item } & & & \multicolumn{7}{|c|}{$\mathrm{AC}$} & \multicolumn{7}{|c|}{ AMTS } \\
\hline & \multicolumn{2}{|c|}{ Observed } & \multirow[b]{2}{*}{ Mean } & \multirow[b]{2}{*}{$\mathrm{SE}$} & \multirow[b]{2}{*}{$\mathrm{RMSPE}^{2}$} & \multirow[b]{2}{*}{$\mathrm{R}^{2}$} & \multicolumn{3}{|c|}{ MSPE bias partition ${ }^{3}$} & \multirow[b]{2}{*}{ Mean } & \multirow[b]{2}{*}{$\mathrm{SE}$} & \multirow[b]{2}{*}{ RMSPE } & \multirow[b]{2}{*}{$\mathrm{R}^{2}$} & \multicolumn{3}{|c|}{ MSPE bias partition } \\
\hline & Mean & $\mathrm{SE}$ & & & & & Mean & Slope & Random & & & & & Mean & Slope & Random \\
\hline $\mathrm{CP}$ & 3,044 & 769 & 2,981 & 705 & 174.1 & 0.95 & 1.2 & 8.0 & 90.8 & 3,094 & 626 & 159.5 & 0.92 & 0.8 & 2.2 & 97.0 \\
\hline $\mathrm{MCP}^{4}$ & 1,572 & 423 & 1,525 & 463 & 233.9 & 0.68 & 1.1 & 32.7 & 66.2 & 1,655 & 326 & 193.3 & 0.78 & 5.0 & 7.6 & 87.4 \\
\hline RUP & 1,515 & 614 & 1,463 & 370 & 191.7 & 0.90 & 1.2 & 0.2 & 98.6 & 1,439 & 366 & 176.2 & 0.91 & 1.6 & 0.1 & 98.3 \\
\hline $\operatorname{Arg}$ & 122 & 38 & 125 & 31 & 11.8 & 0.90 & 0.6 & 9.8 & 89.6 & 155 & 36 & 12.2 & 0.89 & 46.6 & 10.2 & 43.2 \\
\hline His & 62 & 21 & 61 & 18 & 5.8 & 0.92 & 0.2 & 9.5 & 90.3 & 69 & 19 & 6.3 & 0.90 & 13.9 & 10.6 & 75.5 \\
\hline Ile & 116 & 36 & 127 & 32 & 8.9 & 0.94 & 9.2 & 16.8 & 74.0 & 128 & 28 & 8.6 & 0.94 & 11.6 & 11.3 & 77.1 \\
\hline Leu & 235 & 82 & 230 & 62 & 17.6 & 0.95 & 0.8 & 0.5 & 98.7 & 231 & 60 & 16.1 & 0.96 & 0.5 & 0.9 & 98.6 \\
\hline Lys & 153 & 50 & 162 & 43 & 12.5 & 0.93 & 4.5 & 7.8 & 87.7 & 166 & 41 & 11.6 & 0.94 & 9.5 & 4.6 & 85.9 \\
\hline Met & 48 & 17 & 49 & 12 & 3.7 & 0.95 & 0.1 & 1.2 & 98.7 & 55 & 12 & 4.1 & 0.94 & 16.1 & 6.1 & 77.8 \\
\hline Phe & 130 & 38 & 132 & 32 & 10.6 & 0.92 & 0.5 & 3.2 & 96.3 & 140 & 32 & 10.1 & 0.92 & 11.6 & 4.1 & 84.3 \\
\hline Thr & 122 & 34 & 126 & 30 & 8.7 & 0.93 & 1.9 & 5.7 & 92.4 & 122 & 27 & 8.1 & 0.94 & 0.0 & 3.4 & 96.6 \\
\hline Val & 142 & 46 & 148 & 35 & 10.4 & 0.95 & 2.4 & 5.0 & 92.6 & 153 & 37 & 10.6 & 0.95 & 6.2 & 9.0 & 84.8 \\
\hline $\mathrm{CP}$ & & & 3,190 & 615 & 187.7 & 0.94 & 6.3 & 2.5 & 91.2 & 3,022 & 634 & 190.9 & 0.94 & 0.2 & 1.4 & 98.4 \\
\hline MCP & & & 2,014 & 397 & 195.1 & 0.78 & 57.1 & 7.4 & 35.5 & 1,539 & 324 & 199.8 & 0.77 & 0.8 & 7.9 & 91.3 \\
\hline RUP & & & 1,181 & 332 & 250.8 & 0.83 & 26.3 & 1.2 & 72.5 & 1,494 & 395 & 216.5 & 0.87 & 0.2 & 0.0 & 99.8 \\
\hline Arg & & & 163 & 36 & 11.9 & 0.90 & 59.3 & 7.3 & 33.4 & 117 & 25 & 12.1 & 0.89 & 2.3 & 0.6 & 97.1 \\
\hline His & & & 72 & 20 & 5.9 & 0.92 & 24.3 & 15.0 & 60.7 & 58 & 15 & 6.0 & 0.91 & 4.5 & 2.0 & 93.5 \\
\hline Ile & & & 136 & 28 & 8.9 & 0.94 & 27.9 & 6.8 & 65.3 & 120 & 24 & 9.9 & 0.92 & 2.3 & 2.8 & 94.9 \\
\hline Leu & & & 236 & 62 & 16.7 & 0.96 & 0.0 & 1.0 & 99.0 & 237 & 59 & 18.2 & 0.95 & 0.2 & 0.0 & 99.8 \\
\hline Lys & & & 180 & 44 & 12.4 & 0.94 & 34.6 & 4.2 & 61.2 & 161 & 35 & 12.6 & 0.94 & 5.0 & 0.0 & 95.0 \\
\hline Met & & & 61 & 13 & 4.0 & 0.94 & 42.9 & 3.5 & 53.6 & 49 & 10 & 4.0 & 0.94 & 0.0 & 0.2 & 99.8 \\
\hline Phe & & & 145 & 34 & 10.5 & 0.92 & 24.9 & 4.9 & 70.2 & 130 & 28 & 13.1 & 0.87 & 0.0 & 0.4 & 99.6 \\
\hline Thr & & & 129 & 28 & 8.5 & 0.93 & 7.9 & 3.1 & 89.0 & 122 & 24 & 8.9 & 0.93 & 0.1 & 0.0 & 99.9 \\
\hline Val & & & 161 & 38 & 10.5 & 0.95 & 18.1 & 8.0 & 73.9 & 142 & 30 & 11.2 & 0.94 & 0.0 & 0.2 & 99.8 \\
\hline
\end{tabular}

${ }^{1} \mathrm{AC}=$ AminoCow; AMTS = Agricultural Modeling and Training Systems; CPM = Cornell-Penn-Miner version of CNCPS; NRC = National Research Council (2001); see text for details on the versions used.

${ }^{2} \mathrm{RMSPE}=$ root mean square prediction error.

${ }^{3} \mathrm{MSPE}=$ mean square prediction error with percentage due to mean, regression, and random disturbance biases

${ }^{4}$ Microbial CP. 
ated as no added RUP and added RUP, the RMSPE for average EAA flows was smallest for AMTS across both diet types and greatest for CPM on diets with no added RUP and greatest for NRC in diets with added RUP.

\section{Effect of Intake Level}

Protein Fractions. At low intake level, the AC, AMTS, and NRC models predicted CP flow very accurately, whereas CPM overpredicted CP flow by $13 \%$, mainly due to a mean bias. Despite this accuracy in total CP flow, microbial $\mathrm{CP}$ was underpredicted by AC (19\%), AMTS (1\%), and NRC (14\%), whereas CPM overpredicted microbial CP (16\%) flow (Tables 11 and 12). Therefore, RUP was overpredicted by all models, but within acceptable limits for the low intake diets. At high intake level, CP flows were predicted very accurately by all models. All models overpredicted the microbial $\mathrm{CP}$ fraction within an acceptable limit except CPM, which overestimated it by $35 \%$ due to a large mean bias ( $75 \%$ of the error). In contrast, RUP was underestimated by all models but within acceptable limits except for CPM, which underestimated it by $29 \%$. For predictions on both intake levels, AMTS displayed the lowest RMSPE for protein fractions, and CPM displayed the highest.

Individual $\boldsymbol{A} \boldsymbol{A}$. All AA were predicted within an acceptable range on low intake diets by all models, except for CPM, which overpredicted Arg (20\%) and Met (16\%), and NRC, which underpredicted His (17\%) passage to the duodenum (Tables 11 and 12). On high intake diets, AMTS overpredicted Arg (32\%) and His (20\%), whereas CPM overpredicted Arg (39\%), His (26\%), and Met (27\%). For predictions on low DMI diets, CPM displayed the lowest RMSPE for EAA and NRC the highest, whereas on high intake levels, AC displayed the lowest RMSPE and CPM the highest (Tables 11 and 12).

\section{Effect of Dietary CP Level}

Protein Fractions. Flows of CP for cows consuming low CP diets (14.6 $\pm 1.2 \% \mathrm{DM}$; range 10.5-15.8\%) were predicted within acceptable limits by the 4 models (Tables 13 and 14). Microbial CP, however, was underpredicted by AC (18\%) and overpredicted by CPM (26\%). The CPM model again underpredicted RUP (18\%), whereas the other 3 models predicted it very accurately. Error partitioning indicated that the microbial prediction by $\mathrm{AC}$ was a combination of mean and regression biases, whereas the error in the CPM predictions was mainly due to a mean bias (Tables 13 and 14). Predictions of duodenal flow of $\mathrm{CP}$ and $\mathrm{CP}$ fractions of cows on high CP diets by AC, AMTS, and NRC were all acceptable. The CPM model underpredicted RUP (31\%) and overpredicted microbial CP (25\%), with the significant error assigned to mean bias. Model predictions of low CP diets by AMTS had the lowest RMSPE for CP fractions, whereas NRC had the highest RMSPE. However, for high protein diets, NRC displayed the lowest RMSPE for protein fractions and CPM had the highest RMSPE (Tables 13 and 14).

Individual $\boldsymbol{A} \boldsymbol{A}$. Flows of EAA in cows consuming low $\mathrm{CP}$ diets followed the same trend as total CP flow. They were predicted accurately by the AC, AMTS, and NRC models, except that AMTS overpredicted Arg $(23 \%)$ and Met $(17 \%)$ flows. The CPM model overpredicted the flow of most EAA and was outside acceptable limits for Arg (31\%), Lys (16\%), and Met (31\%). Error partitioning indicated the presence of mean bias in the predictions of AMTS and CPM (Tables 13 and 14). Predictions of EAA flows of high CP diets by AC, AMTS, and NRC were all within acceptable limits, except for Arg prediction by AMTS, which was $25 \%$ greater than observed. The CPM model overpredicted Arg (25\%) and Met (23\%). All of the significant errors for high CP diets were attributable to mean bias. Model predictions of low CP diets by CPM displayed the lowest RMSPE for EAA and AC the highest. However, for high protein diets, AC displayed the lowest RMSPE for EAA, whereas CPM had the highest RMSPE (Tables 13 and 14).

\section{Effect of NDF Level}

Protein Fractions. Prediction of total CP flow was accurate for all models for diets that were low in NDF (27.1 $\pm 2.1 \%$ DM; range 21.7-29.4), although all models predicted smaller RUP flow than the observed values: within acceptable limits for AC (12\%), AMTS (14\%), and NRC (11\%) but outside acceptable limits for CPM (30\%; Tables 15 and 16). In addition, microbial CP was overpredicted by CPM (21\%). The error was partitioned between mean and slope biases for AC, AMTS, and NRC, whereas it was mainly due to mean bias for CPM. For high NDF diets, prediction of total $\mathrm{CP}$ flow by all models were highly accurate (Tables 15 and 16). The AC, AMTS, and NRC models also very accurately predicted the flow of microbial $\mathrm{CP}$, whereas CPM overpredicted microbial CP by $19 \%$. The high microbial flow predicted by CPM was due to a mix of mean and regression biases. The RUP flows were very accurately predicted, except for the CPM prediction, which was barely within acceptable limits. Predictions for low and high NDF diets resulted in AMTS having, on average, the lowest RMSPE for protein fractions. 
Table 11. Observed and predicted duodenal flows $(\mathrm{g} / \mathrm{d})$, and statistical adequacy of 4 programs $^{1}$ for rations at low $(<17 \mathrm{~kg} / \mathrm{d}) \mathrm{DMI}(\mathrm{n}=45)$

\begin{tabular}{|c|c|c|c|c|c|c|c|c|c|c|c|c|c|c|c|}
\hline \multirow{2}{*}{\multicolumn{2}{|c|}{ Observed }} & \multicolumn{7}{|c|}{$\mathrm{AC}$} & \multicolumn{7}{|c|}{ AMTS } \\
\hline & & \multirow[b]{2}{*}{ Mean } & \multirow[b]{2}{*}{$\mathrm{SE}$} & \multirow[b]{2}{*}{$\mathrm{RMSPE}^{2}$} & \multirow[b]{2}{*}{$\mathrm{R}^{2}$} & \multicolumn{3}{|c|}{ MSPE bias partition ${ }^{3}$} & \multirow[b]{2}{*}{ Mean } & \multirow[b]{2}{*}{$\mathrm{SE}$} & \multirow[b]{2}{*}{ RMSPE } & \multirow[b]{2}{*}{$\mathrm{R}^{2}$} & \multicolumn{3}{|c|}{ MSPE bias partition } \\
\hline Mean & $\mathrm{SE}$ & & & & & Mean & Slope & Random & & & & & Mean & Slope & Random \\
\hline 2,175 & 557 & 2,094 & 507 & 131.9 & 0.94 & 2.5 & 15.4 & 82.1 & 2,267 & 462 & 119.7 & 0.95 & 4.5 & 4.6 & 90.9 \\
\hline 1,368 & 462 & 1,103 & 298 & 143.8 & 0.90 & 21.0 & 5.50 & 73.5 & 1,355 & 266 & 140.7 & 0.90 & 0.5 & 4.6 & 94.9 \\
\hline 898 & 396 & 1,024 & 345 & 118.2 & 0.90 & 17.1 & 4.00 & 78.9 & 912 & 325 & 99.0 & 0.93 & 4.4 & 2.1 & 93.5 \\
\hline 97 & 49 & 87 & 22 & 10.4 & 0.95 & 4.6 & 0.5 & 94.9 & 109 & 28 & 10.2 & 0.95 & 6.6 & 2.3 & 91.1 \\
\hline 48 & 27 & 42 & 14 & 3.8 & 0.98 & 6.2 & 0.1 & 93.7 & 46 & 14 & 4.6 & 0.97 & 0.4 & 1.1 & 98.5 \\
\hline 93 & 32 & 91 & 24 & 6.7 & 0.95 & 0.7 & 16.7 & 82.6 & 93 & 21 & 6.2 & 0.96 & 0.2 & 0.9 & 98.9 \\
\hline 159 & 65 & 156 & 47 & 14.4 & 0.95 & 0.8 & 0.2 & 99.0 & 157 & 48 & 14.0 & 0.95 & 0.4 & 2.4 & 97.2 \\
\hline 115 & 33 & 115 & 27 & 8.1 & 0.94 & 0.0 & 22.5 & 77.5 & 119 & 31 & 7.8 & 0.94 & 1.3 & 10.9 & 87.8 \\
\hline 37 & 17 & 33 & 8 & 3.8 & 0.94 & 8.0 & 0.4 & 91.6 & 40 & 8 & 3.8 & 0.94 & 2.4 & 3.2 & 94.4 \\
\hline 92 & 33 & 92 & 23 & 8.8 & 0.92 & 0.0 & 0.5 & 99.5 & 98 & 25 & 8.7 & 0.92 & 8.1 & 0.1 & 91.8 \\
\hline 96 & 34 & 89 & 19 & 7.0 & 0.95 & 4.5 & 0.4 & 95.1 & 87 & 20 & 6.5 & 0.96 & 9.6 & 1.3 & 89.1 \\
\hline \multirow[t]{13}{*}{104} & 37 & 105 & 25 & 7.8 & 0.95 & 0.1 & 6.2 & 93.7 & 102 & 19 & 7.7 & 0.95 & 2.3 & 3.0 & 94.7 \\
\hline & & 2,448 & 474 & 141.8 & 0.93 & 31.3 & 3.0 & 65.7 & 2,127 & 425 & 144.4 & 0.93 & 1.1 & 5.1 & 93.8 \\
\hline & & 1,581 & 306 & 149.2 & 0.89 & 38.5 & 0.4 & 61.1 & 1,182 & 206 & 148.5 & 0.89 & 13.4 & 3.0 & 83.6 \\
\hline & & 912 & 300 & 137.5 & 0.88 & 0.2 & 4.2 & 95.6 & 978 & 312 & 111.8 & 0.91 & 8.7 & 0.4 & 90.9 \\
\hline & & 116 & 27 & 10.6 & 0.95 & 15.6 & 1.1 & 83.3 & 83 & 18 & 10.8 & 0.95 & 8.6 & 0.2 & 91.2 \\
\hline & & 49 & 15 & 4.2 & 0.97 & 0.5 & 0.3 & 99.2 & 40 & 11 & 4.0 & 0.97 & 11.1 & 3.6 & 85.3 \\
\hline & & 99 & 21 & 5.8 & 0.96 & 3.7 & 0.6 & 95.7 & 88 & 15 & 8.4 & 0.92 & 4.4 & 0.4 & 95.2 \\
\hline & & 162 & 47 & 12.8 & 0.96 & 0.6 & 5.2 & 94.2 & 161 & 45 & 15.7 & 0.92 & 0.1 & 0.7 & 99.2 \\
\hline & & 130 & 29 & 7.4 & 0.95 & 20.4 & 9.9 & 69.7 & 117 & 21 & 8.4 & 0.93 & 0.4 & 8.7 & 90.9 \\
\hline & & 43 & 9 & 3.6 & 0.95 & 17.8 & 2.0 & 80.2 & 34 & 6 & 3.7 & 0.95 & 5.6 & 2.1 & 92.3 \\
\hline & & 103 & 25 & 8.6 & 0.92 & 21.9 & 0.0 & 78.1 & 91 & 20 & 9.2 & 0.91 & 0.0 & 0.1 & 99.9 \\
\hline & & 94 & 21 & 6.6 & 0.96 & 0.6 & 0.4 & 99.0 & 89 & 16 & 7.2 & 0.95 & 4.1 & 0.1 & 95.8 \\
\hline & & 115 & 29 & 6.5 & 0.97 & 14.0 & 1.8 & 84.2 & 102 & 19 & 8.8 & 0.94 & 0.3 & 0.1 & 99.6 \\
\hline
\end{tabular}

${ }^{1} \mathrm{AC}=$ AminoCow; AMTS = Agricultural Modeling and Training Systems; CPM = Cornell-Penn-Miner version of CNCPS; NRC = National Research Council (2001); see text for details on the versions used.

${ }^{2} \mathrm{RMSPE}=$ root mean square prediction error.

${ }^{3} \mathrm{MSPE}=$ mean square prediction error with percentage due to mean, regression, and random disturbance biases

${ }^{4}$ Microbial CP. 
Table 12. Observed and predicted duodenal flows $(\mathrm{g} / \mathrm{d})$, and statistical adequacy of 4 programs ${ }^{1}$ for rations at high $(>22 \mathrm{~kg} / \mathrm{d}) \mathrm{DMI}(\mathrm{n}=42)$

\begin{tabular}{|c|c|c|c|c|c|c|c|c|c|c|c|c|c|c|c|c|}
\hline \multirow[b]{3}{*}{ Item } & & & \multicolumn{7}{|c|}{$\mathrm{AC}$} & \multicolumn{7}{|c|}{ AMTS } \\
\hline & \multicolumn{2}{|c|}{ Observed } & \multirow[b]{2}{*}{ Mean } & \multirow[b]{2}{*}{$\mathrm{SE}$} & \multirow[b]{2}{*}{$\mathrm{RMSPE}^{2}$} & \multirow[b]{2}{*}{$\mathrm{R}^{2}$} & \multicolumn{3}{|c|}{ MSPE bias partition ${ }^{3}$} & \multirow[b]{2}{*}{ Mean } & \multirow[b]{2}{*}{$\mathrm{SE}$} & \multirow[b]{2}{*}{ RMSPE } & \multirow[b]{2}{*}{$\mathrm{R}^{2}$} & \multicolumn{3}{|c|}{ MSPE bias partition } \\
\hline & Mean & $\mathrm{SE}$ & & & & & Mean & Slope & Random & & & & & Mean & Slope & Random \\
\hline $\mathrm{CP}$ & 3,671 & 416 & 3,739 & 386 & 171.5 & 0.82 & 1.8 & 34.8 & 63.4 & 3,639 & 286 & 176.4 & 0.81 & 0.4 & 34.8 & 64.8 \\
\hline $\mathrm{MCP}^{4}$ & 1,833 & 268 & 2,092 & 308 & 105.1 & 0.83 & 35.1 & 30.3 & 34.6 & 1.927 & 181 & 108.7 & 0.82 & 7.0 & 39.4 & 53.6 \\
\hline RUP & 1,842 & 379 & 1,647 & 249 & 178.3 & 0.84 & 20.5 & 9.7 & 69.8 & 1,712 & 279 & 171.6 & 0.78 & 10.8 & 7.0 & 82.2 \\
\hline Arg & 141 & 22 & 155 & 16 & 9.3 & 0.81 & 24.1 & 15.9 & 60.0 & 186 & 14 & 10.1 & 0.78 & 77.5 & 4.2 & 18.3 \\
\hline His & 69 & 10 & 76 & 14 & 6.0 & 0.65 & 17.9 & 41.0 & 41.1 & 83 & 14 & 5.0 & 0.75 & 48.4 & 26.4 & 25.2 \\
\hline Ile & 141 & 30 & 160 & 18 & 8.4 & 0.91 & 27.5 & 8.7 & 63.8 & 152 & 10 & 9.7 & 0.88 & 10.1 & 10.3 & 79.6 \\
\hline Leu & 293 & 46 & 278 & 41 & 17.5 & 0.84 & 7.7 & 24.6 & 67.7 & 269 & 38 & 16.6 & 0.86 & 17.1 & 22.3 & 60.6 \\
\hline Lys & 193 & 34 & 208 & 24 & 14.2 & 0.81 & 14.5 & 15.2 & 70.3 & 202 & 21 & 12.9 & 0.85 & 7.7 & 6.4 & 85.9 \\
\hline Met & 56 & 11 & 60 & 6 & 3.1 & 0.92 & 10.8 & 6.5 & 82.7 & 62 & 6 & 3.4 & 0.90 & 21.7 & 2.8 & 75.5 \\
\hline Phe & 158 & 19 & 161 & 20 & 10.5 & 0.68 & 1.5 & 46.0 & 52.5 & 164 & 19 & 11.0 & 0.65 & 4.0 & 47.6 & 48.4 \\
\hline Thr & 150 & 20 & 158 & 16 & 7.6 & 0.85 & 12.7 & 14.8 & 72.5 & 147 & 12 & 7.4 & 0.86 & 2.4 & 10.2 & 87.4 \\
\hline Val & 173 & 29 & 183 & 21 & 10.0 & 0.88 & 9.2 & 20.3 & 70.5 & 180 & 21 & 11.1 & 0.85 & 3.4 & 36.1 & 60.5 \\
\hline $\mathrm{CP}$ & & & 3,776 & 350 & 206.7 & 0.73 & 3.1 & 51.0 & 45.9 & 3.695 & 334 & 187.9 & 0.78 & 0.3 & 22.3 & 77.4 \\
\hline MCP & & & 2,471 & 171 & 111.6 & 0.81 & 75.2 & 13.8 & 11.0 & 1,943 & 112 & 110.8 & 0.82 & 13.5 & 9.1 & 77.4 \\
\hline RUP & & & 1,305 & 284 & 226.1 & 0.62 & 60.9 & 10.2 & 28.9 & 1,751 & 295 & 193.3 & 0.72 & 5.9 & 12.5 & 81.6 \\
\hline Arg & & & 196 & 12 & 10.4 & 0.76 & 80.8 & 6.7 & 12.5 & 145 & 11 & 9.7 & 0.80 & 3.4 & 5.7 & 90.9 \\
\hline His & & & 87 & 16 & 5.3 & 0.72 & 52.4 & 31.0 & 16.6 & 71 & 10 & 5.5 & 0.71 & 4.4 & 30.7 & 64.9 \\
\hline Ile & & & 162 & 11 & 9.9 & 0.88 & 30.8 & 11.6 & 57.6 & 148 & 11 & 9.2 & 0.90 & 5.5 & 1.8 & 92.7 \\
\hline Leu & & & 274 & 44 & 17.9 & 0.84 & 9.1 & 35.5 & 55.4 & 282 & 37 & 17.7 & 0.84 & 4.6 & 19.1 & 76.3 \\
\hline Lys & & & 222 & 25 & 16.7 & 0.74 & 37.5 & 13.5 & 49.0 & 201 & 16 & 13.1 & 0.84 & 6.5 & 1.3 & 92.2 \\
\hline Met & & & 71 & 6 & 3.2 & 0.92 & 66.8 & 1.0 & 32.2 & 58 & 5 & 3.3 & 0.91 & 3.8 & 1.3 & 94.9 \\
\hline Phe & & & 171 & 22 & 11.5 & 0.61 & 14.1 & 53.5 & 32.4 & 157 & 16 & 11.2 & 0.63 & 0.3 & 34.9 & 64.8 \\
\hline Thr & & & 157 & 13 & 8.2 & 0.83 & 7.3 & 27.2 & 65.5 & 150 & 11 & 8.2 & 0.82 & 0.0 & 5.4 & 94.6 \\
\hline Val & & & 191 & 26 & 11.2 & 0.84 & 16.4 & 40.7 & 42.9 & 172 & 18 & 10.5 & 0.86 & 0.2 & 16.7 & 83.1 \\
\hline $\begin{array}{l}{ }^{1} \mathrm{AC}= \\
\text { details } \\
{ }^{2} \mathrm{RMSP} \\
{ }^{3} \mathrm{MSPE} \\
{ }^{4} \mathrm{Microl}\end{array}$ & $\begin{array}{l}\text { minoCow; } \\
\mathrm{n} \text { the versi } \\
=\text { root } \mathrm{m} \\
=\text { mean } \mathrm{sq} \\
\text { al } \mathrm{CP} \text {. }\end{array}$ & $\begin{array}{l}\text { AMTS } \\
\text { as use } \\
\text { an squ } \\
\text { are pr }\end{array}$ & $\begin{array}{l}\text { gricultur } \\
\text { redictior } \\
\text { on error }\end{array}$ & $\begin{array}{l}\text { Mode } \\
\text { rror. } \\
\text { ith pe }\end{array}$ & ng and Trai & ng Syst & $\mathrm{ms} ; \mathrm{CPI}$ & $=$ Corn & Penn-Min & sion of & TCPS; & $\mathrm{RC}=\mathrm{Nat}$ & al Res & irch Cou & cil (2001 & see text $f$ \\
\hline
\end{tabular}


Table 13. Observed and predicted duodenal flows $(\mathrm{g} / \mathrm{d})$, and statistical adequacy of 4 programs ${ }^{1}$ for rations with low $\mathrm{CP}$ concentration $(\mathrm{CP}=14.6 \pm 1.2 \%$; $=41)$

re $\mathrm{AC}$

\begin{tabular}{|c|c|c|c|c|c|c|c|c|c|c|c|c|c|c|c|c|}
\hline \multirow[b]{3}{*}{ Item } & & & \multicolumn{7}{|c|}{$\mathrm{AC}$} & \multicolumn{7}{|c|}{ AMTS } \\
\hline & \multicolumn{2}{|c|}{ Observed } & \multirow[b]{2}{*}{ Mean } & \multirow[b]{2}{*}{$\mathrm{SE}$} & \multirow[b]{2}{*}{$\mathrm{RMSPE}^{2}$} & \multirow[b]{2}{*}{$\mathrm{R}^{2}$} & \multicolumn{3}{|c|}{ MSPE bias partition ${ }^{3}$} & \multirow[b]{2}{*}{ Mean } & \multirow[b]{2}{*}{$\mathrm{SE}$} & \multirow[b]{2}{*}{ RMSPE } & \multirow[b]{2}{*}{$\mathrm{R}^{2}$} & \multicolumn{3}{|c|}{ MSPE bias partition } \\
\hline & Mean & $\mathrm{SE}$ & & & & & Mean & Slope & Random & & & & & Mean & Slope & Random \\
\hline $\mathrm{CP}$ & 2,634 & 780 & 2,330 & 653 & 150.4 & 0.96 & 26.5 & 1.4 & 72.1 & 2,461 & 625 & 105.7 & 0.98 & 0.0 & 0.9 & 99.1 \\
\hline $\mathrm{MCP}^{4}$ & 1,526 & 450 & 1,244 & 423 & 198.2 & 0.79 & 21.9 & 26.6 & 51.5 & 1,599 & 102 & 100.6 & 0.95 & 6.9 & 0.8 & 92.3 \\
\hline RUP & 1,151 & 536 & 1,154 & 314 & 130.8 & 0.94 & 0.0 & 0.9 & 99.1 & 1,120 & 321 & 118.0 & 0.95 & 0.7 & 3.3 & 96.0 \\
\hline Arg & 105 & 42 & 98 & 29 & 8.5 & 0.96 & 4.6 & 0.3 & 95.1 & 129 & 36 & 9.0 & 0.95 & 34.3 & 4.1 & 61.6 \\
\hline $\mathrm{His}$ & 51 & 17 & 46 & 14 & 4.6 & 0.93 & 12.3 & 0.8 & 86.9 & 54 & 16 & 3.8 & 0.95 & 11.0 & 2.8 & 86.2 \\
\hline Ile & 105 & 37 & 102 & 30 & 6.9 & 0.96 & 1.1 & 10.7 & 88.2 & 109 & 28 & 6.1 & 0.97 & 1.8 & 0.7 & 97.5 \\
\hline Leu & 190 & 80 & 172 & 51 & 16.3 & 0.96 & 10.5 & 2.4 & 87.1 & 183 & 56 & 10.2 & 0.98 & 2.6 & 4.4 & 93.0 \\
\hline Lys & 135 & 49 & 128 & 38 & 9.0 & 0.96 & 2.8 & 7.2 & 90.0 & 141 & 40 & 9.1 & 0.96 & 2.5 & 0.9 & 96.6 \\
\hline Met & 41 & 17 & 39 & 11 & 3.8 & 0.95 & 4.3 & 1.4 & 94.3 & 48 & 12 & 4.1 & 0.94 & 23.6 & 0.0 & 76.4 \\
\hline Phe & 105 & 37 & 101 & 28 & 9.2 & 0.94 & 2.6 & 0.1 & 97.3 & 113 & 30 & 7.6 & 0.96 & 9.6 & 0.0 & 90.4 \\
\hline Thr & 101 & 32 & 100 & 27 & 6.6 & 0.96 & 0.4 & 6.8 & 92.8 & 102 & 26 & 5.4 & 0.97 & 0.1 & 0.4 & 99.5 \\
\hline Val & 121 & 44 & 115 & 31 & 8.4 & 0.96 & 3.2 & 1.2 & 95.6 & 124 & 32 & 8.6 & 0.96 & 0.9 & 0.0 & 99.1 \\
\hline $\mathrm{CP}$ & & & 2,809 & 693 & 140.3 & 0.96 & 15.6 & 0.4 & 84.0 & 2,483 & 614 & 188.8 & 0.94 & 6.9 & 1.1 & 92.0 \\
\hline MCP & & & 1,930 & 448 & 119.8 & 0.92 & 60.4 & 5.2 & 34.4 & 1,380 & 320 & 177.4 & 0.83 & 12.6 & 34.6 & 52.8 \\
\hline RUP & & & 943 & 307 & 182.8 & 0.87 & 15.3 & 2.4 & 82.3 & 1,177 & 358 & 157.9 & 0.91 & 0.0 & 14.8 & 85.2 \\
\hline $\mathrm{Arg}$ & & & 138 & 39 & 6.8 & 0.97 & 56.3 & 3.0 & 40.7 & 96 & 25 & 8.2 & 0.96 & 7.5 & 1.1 & 91.4 \\
\hline His & & & 58 & 17 & 2.9 & 0.97 & 32.1 & 5.1 & 62.8 & 46 & 13 & 4.7 & 0.92 & 16.8 & 0.6 & 82.6 \\
\hline Ile & & & 118 & 31 & 5.0 & 0.98 & 24.0 & 0.5 & 75.5 & 101 & 23 & 7.1 & 0.96 & 2.0 & 0.9 & 97.1 \\
\hline Leu & & & 189 & 57 & 10.3 & 0.98 & 0.1 & 9.3 & 90.6 & 185 & 52 & 12.4 & 0.97 & 1.4 & 7.3 & 91.3 \\
\hline Lys & & & 156 & 41 & 7.3 & 0.98 & 31.6 & 0.8 & 67.6 & 135 & 32 & 9.3 & 0.96 & 0.0 & 0.0 & 100.0 \\
\hline Met & & & 54 & 14 & 3.5 & 0.96 & 62.0 & 0.0 & 38.0 & 41 & 10 & 3.9 & 0.94 & 0.2 & 6.5 & 93.3 \\
\hline Phe & & & 119 & 32 & 7.2 & 0.96 & 36.2 & 0.0 & 63.8 & 104 & 26 & 9.2 & 0.93 & 0.2 & 2.3 & 97.5 \\
\hline Thr & & & 110 & 29 & 4.8 & 0.98 & 19.1 & 0.8 & 80.1 & 102 & 24 & 6.5 & 0.96 & 0.2 & 0.0 & 99.8 \\
\hline Val & & & 133 & 35 & 6.6 & 0.98 & 18.8 & 0.1 & 81.1 & 116 & 26 & 8.6 & 0.96 & 2.7 & 3.5 & 93.8 \\
\hline
\end{tabular}

${ }^{1}$ AC $=$ AminoCow; AMTS = Agricultural Modeling and Training Systems; CPM = Cornell-Penn-Miner version of CNCPS; NRC = National Research Council (2001); see text for details on the versions used.

${ }^{2} \mathrm{RMSPE}=$ root mean square prediction error.

${ }^{3} \mathrm{MSPE}=$ mean square prediction error with percentage due to mean, regression, and random disturbance biases.

${ }^{4}$ Microbial CP. 
Table 14. Observed and predicted duodenal flows $(\mathrm{g} / \mathrm{d})$, and statistical adequacy of 4 programs ${ }^{1}$ for rations with high $\mathrm{CP}$ concentration $(\mathrm{CP}=18.3 \pm 0.9 \% ; \mathrm{n}=55)$

\begin{tabular}{|c|c|c|c|c|c|c|c|c|c|c|c|c|c|c|c|c|}
\hline \multirow[b]{3}{*}{ Item } & & & \multicolumn{7}{|c|}{$\mathrm{AC}$} & \multicolumn{7}{|c|}{ AMTS } \\
\hline & \multicolumn{2}{|c|}{ Observed } & \multirow[b]{2}{*}{ Mean } & \multirow[b]{2}{*}{$\mathrm{SE}$} & \multirow[b]{2}{*}{$\mathrm{RMSPE}^{2}$} & \multirow[b]{2}{*}{$\mathrm{R}^{2}$} & \multicolumn{3}{|c|}{ MSPE bias partition ${ }^{3}$} & \multirow[b]{2}{*}{ Mean } & \multirow[b]{2}{*}{$\mathrm{SE}$} & \multirow[b]{2}{*}{ RMSPE } & \multirow[b]{2}{*}{$\mathrm{R}^{2}$} & \multicolumn{3}{|c|}{ MSPE bias partition } \\
\hline & Mean & $\mathrm{SE}$ & & & & & Mean & Slope & Random & & & & & Mean & Slope & Random \\
\hline $\mathrm{CP}$ & 3,428 & 671 & 3,462 & 520 & 155.7 & 0.94 & 0.5 & 1.6 & 97.9 & 3,352 & 489 & 165.2 & 0.94 & 2.1 & 1.3 & 96.6 \\
\hline $\mathrm{MCP}^{4}$ & 1,719 & 329 & 1,912 & 326 & 203.7 & 0.59 & 30.6 & 15.9 & 53.5 & 1,750 & 254 & 211.5 & 0.56 & 1.4 & 16.6 & 82.0 \\
\hline RUP & 1,787 & 596 & 1,562 & 328 & 227.3 & 0.85 & 16.4 & 0.1 & 83.5 & 1,629 & 294 & 224.3 & 0.85 & 9.4 & 0.5 & 90.1 \\
\hline $\mathrm{Arg}$ & 138 & 29 & 144 & 25 & 12.4 & 0.81 & 5.6 & 13.8 & 80.6 & 172 & 28 & 12.6 & 0.80 & 56.5 & 10.9 & 32.6 \\
\hline His & 68 & 15 & 69 & 15 & 6.7 & 0.80 & 0.5 & 18.3 & 81.2 & 75 & 16 & 6.9 & 0.78 & 20.7 & 17.7 & 61.6 \\
\hline Ile & 133 & 34 & 151 & 23 & 9.7 & 0.92 & 31.6 & 0.0 & 68.4 & 142 & 21 & 9.8 & 0.92 & 6.0 & 8.1 & 85.9 \\
\hline Leu & 260 & 78 & 260 & 54 & 16.3 & 0.95 & 0.7 & 0.2 & 99.1 & 250 & 53 & 16.1 & 0.95 & 0.8 & 2.5 & 96.7 \\
\hline Lys & 173 & 40 & 191 & 31 & 10.9 & 0.92 & 27.3 & 1.6 & 71.1 & 184 & 31 & 11.6 & 0.91 & 8.4 & 8.7 & 82.9 \\
\hline Met & 52 & 14 & 56 & 9 & 3.0 & 0.95 & 14.8 & 0.2 & 85.0 & 58 & 9 & 3.2 & 0.94 & 16.8 & 12.5 & 70.7 \\
\hline Phe & 148 & 31 & 152 & 26 & 9.5 & 0.90 & 3.4 & 1.3 & 95.3 & 152 & 26 & 9.8 & 0.89 & 3.0 & 9.9 & 87.1 \\
\hline Thr & 140 & 27 & 146 & 22 & 7.9 & 0.91 & 7.3 & 3.7 & 89.0 & 134 & 21 & 8.2 & 0.90 & 5.0 & 8.6 & 86.4 \\
\hline Val & 159 & 43 & 169 & 28 & 9.6 & 0.95 & 33.2 & 5.5 & 61.3 & 164 & 29 & 10.2 & 0.94 & 1.8 & 8.3 & 89.9 \\
\hline $\mathrm{CP}$ & & & 3,378 & 475 & 192.5 & 0.91 & 0.8 & 3.4 & 95.8 & 3,345 & 525 & 142.8 & 0.95 & 2.9 & 1.3 & 95.8 \\
\hline MCP & & & 2,157 & 317 & 211.3 & 0.56 & 57.2 & 14.8 & 28.0 & 1,738 & 240 & 198.2 & 0.61 & 1.2 & 8.7 & 90.1 \\
\hline RUP & & & 1,234 & 263 & 285.0 & 0.76 & 47.2 & 2.1 & 50.7 & 1,622 & 350 & 231.2 & 0.84 & 10.8 & 0.0 & 89.2 \\
\hline Arg & & & 178 & 29 & 13.4 & 0.77 & 63.0 & 10.5 & 26.5 & 133 & 22 & 13.2 & 0.78 & 3.1 & 7.7 & 89.2 \\
\hline His & & & 77 & 18 & 7.4 & 0.75 & 27.3 & 24.9 & 47.8 & 64 & 13 & 7.0 & 0.78 & 7.5 & 9.4 & 83.1 \\
\hline Ile & & & 149 & 22 & 10.4 & 0.90 & 19.3 & 4.9 & 75.8 & 137 & 21 & 10.0 & 0.91 & 2.0 & 0.6 & 97.4 \\
\hline Leu & & & 252 & 58 & 17.9 & 0.94 & 0.4 & 4.6 & 95.0 & 261 & 54 & 17.3 & 0.95 & 0.9 & 0.1 & 99.0 \\
\hline Lys & & & 197 & 35 & 13.7 & 0.87 & 29.5 & 10.2 & 60.3 & 182 & 28 & 11.2 & 0.92 & 8.1 & 0.2 & 91.7 \\
\hline Met & & & 64 & 10 & 3.1 & 0.95 & 47.6 & 5.1 & 47.3 & 53 & 8 & 3.1 & 0.95 & 2.3 & 0.5 & 97.2 \\
\hline Phe & & & 156 & 29 & 11.0 & 0.86 & 8.7 & 16.1 & 75.2 & 144 & 25 & 13.0 & 0.81 & 1.9 & 4.2 & 93.9 \\
\hline Thr & & & 141 & 23 & 8.9 & 0.89 & 0.1 & 13.5 & 86.4 & 137 & 21 & 8.2 & 0.90 & 2.8 & 1.7 & 95.5 \\
\hline Val & & & 171 & 32 & 10.4 & 0.94 & 10.1 & 7.5 & 82.4 & 157 & 25 & 10.0 & 0.94 & 0.6 & 1.4 & 98.0 \\
\hline $\begin{array}{l}{ }^{1} \mathrm{AC}= \\
\text { details } \\
{ }^{2} \mathrm{RMSP} \\
{ }^{3} \mathrm{MSPE} \\
{ }^{4} \mathrm{Microl}\end{array}$ & $\begin{array}{l}\text { AminoCow } \\
\text { n the vers } \\
\mathrm{E}=\text { root } \mathrm{m} \\
=\text { mean } \mathrm{sc} \\
\text { ial } \mathrm{CP} \text {. }\end{array}$ & $\begin{array}{l}\text { AMT } \\
\text { ns us }\end{array}$ & $\begin{array}{l}\text { Agricultu } \\
\text { predictio } \\
\text { tion erro }\end{array}$ & $\begin{array}{l}\text { Moc } \\
\text { error } \\
\text { with } p\end{array}$ & ing and Tra & ing Sys & $\mathrm{ms}$; CP & $=$ Corn & l-Penn-Mir & rsion of & NCPS & $\mathrm{NRC}=\mathrm{Na}$ & nal Res & $\operatorname{arch~Cor~}$ & cil $(200$ & see text $\mathrm{f}$ \\
\hline
\end{tabular}


On low NDF diets, CPM had the largest RMSPE for protein fractions, whereas for high NDF diets, NRC had the largest.

Individual $\boldsymbol{A} \boldsymbol{A}$. For diets that were low in NDF, EAA flows were underpredicted within acceptable limits by AC, AMTS, and NRC, with predictions for Leu by AC and Arg by ATMS just barely useful. Arginine (21\%) was overpredicted by CPM, and Met was just on the limit (15\%) for acceptability. For high NDF diets, AC and NRC predicted all AA within acceptable limits. The AMTS model overpredicted Arg (29\%) and Met (23\%). The CPM model overpredicted Arg (36\%), His $(20 \%)$, Ile (17\%), Met (38\%), and Val (17\%). Most of these inaccuracies were associated with a mean bias, but errors for Met in AMTS and His in CPM were due to a combination of mean and regression biases for high NDF diets (Tables 15 and 16). Predictions for low NDF diets resulted in AC having, on average, the lowest RMSPE for EAA, whereas CPM had the largest RMSPE. For high NDF diets, NRC had the largest RMSPE, whereas the 3 other models had very similar values.

\section{DMI}

Because many nutritionists use the respective model default DMI prediction without adjustment to balance dairy rations, we wanted to investigate the accuracy of model prediction of DMI for this data set using the same statistical model as for protein flows. The observed DMI averaged $19.1 \pm 3.8 \mathrm{~kg} / \mathrm{d}$. The prediction of DMI by AC was $18.9 \pm 2.6 \mathrm{~kg} / \mathrm{d}$; AMTS and CPM predicted 18.2 and $18.0 \pm 2.5 \mathrm{~kg} / \mathrm{d}$, respectively; and NRC predicted $19.5 \pm 2.9 \mathrm{~kg} / \mathrm{d}$. The RMSPE was low for all diets, averaging $0.97,0.98,1.00$, and 0.89 for $\mathrm{AC}$, AMTS, CPM, and NRC, respectively.

\section{DISCUSSION}

Models are an attempt to describe mathematically a real-world situation (McNamara, 2004). To predict the duodenal flow of CP fractions and EAA of adult dairy cows, the models evaluated here had to estimate complex rumen processes of microbial protein synthesis, ruminal escape of dietary protein and their AA concentrations, and where calculated, the flow of endogenous protein and its AA pattern. From dietary constituents and cow data such as BW and DMI, these models of rumen digestion use different assumptions: many of these are based upon models that have been previously developed and include features of Molly (Baldwin et al., 1987), INRA (1989), and various editions of NRC $(1978,1989)$. Models also emphasize different aspects of studies and employ different approaches and equations to arrive at predictions, for example factorial summations versus empirical equations for estimating AA duodenal flows (discussed by Pacheco et al., 2006). As different models may require many or fewer inputs, the evaluation of a model by a working nutritionist may not necessarily assess which is best in absolute terms, but which is best in terms of resources spent and the accuracy obtained.

The primary differences between this study and previous evaluations of rumen $\mathrm{CP}$ and $\mathrm{AA}$ flows include the evaluation of models across a wide diversity of forage and concentrate ingredients as well as feeding levels and management. In addition, in all studies used in the current analysis, the duodenal protein fractions and EAA flows were measured in the same cows. The models evaluated in this study were reasonably robust when diets included corn as the primary grain and combinations of corn and alfalfa as the forage base. For diets based on other forages or on non-corn energy sources, the partition of CP duodenal flows into microbial CP and RUP was shifted among models. Generally, the AC, AMTS, and NRC models behaved similarly. Within grass-based diets, although the CP flows were estimated very accurately, a systematic underestimation of microbial CP was found, leading to an increased contribution of RUP, which tended to yield lower EAA flows. In contrast to non-corn-based diets, in cornbased diets a trend was observed for lower total $\mathrm{CP}$ and microbial CP flows for AC and NRC models and lower RUP flows for AC, AMTS, and NRC models. However, on average, the EAA flows were not underestimated and were even overestimated by AMTS. This may be due to the flow or to the prediction of EAA composition of different protein fractions, or to both (Lanzas et al., 2007). It was sobering to note that none of the models could be considered accurate and precise at same time for RUP and various EAA (this information is summarized in Table 17). Possible reasons underlying these differences will be discussed by model.

\section{CNCPS Models}

The AMTS and CPM models are both developed from the CNCPS system and thus share many characteristics. Briefly, both models assume 2 types of rumen bacteria: those that ferment fiber and those that ferment nonstructural carbohydrate (Fox et al., 2004; Tylutki et al., 2008). Dietary proteins are divided into 5 fractions depending on protein solubility determined from laboratory procedures in both models, where the first fraction (A) is NPN and contributes N only to RDP and to microbial synthesis, and the last fraction (C) is completely undegradable in the rumen. Flow of RUP to the duodenum is determined by the relative rate of degradation $(\mathbf{k d})$ and rate of passage $(\mathbf{k p})$ of 
Table 15. Observed and predicted duodenal flows $(\mathrm{g} / \mathrm{d})$, and statistical adequacy of 4 programs ${ }^{1}$ for rations with low NDF concentration $(\mathrm{NDF}=27.1 \pm 2.1 \% ; \mathrm{n}=48)$

\begin{tabular}{|c|c|c|c|c|c|c|c|c|c|c|c|c|c|c|c|c|}
\hline \multirow[b]{3}{*}{ Item } & & & \multicolumn{7}{|c|}{$\mathrm{AC}$} & \multicolumn{7}{|c|}{ AMTS } \\
\hline & \multicolumn{2}{|c|}{ Observed } & \multirow[b]{2}{*}{ Mean } & \multirow[b]{2}{*}{$\mathrm{SE}$} & \multirow[b]{2}{*}{$\mathrm{RMSPE}^{2}$} & \multirow[b]{2}{*}{$\mathrm{R}^{2}$} & \multicolumn{3}{|c|}{ MSPE bias partition ${ }^{3}$} & \multirow[b]{2}{*}{ Mean } & \multirow[b]{2}{*}{ SE } & \multirow[b]{2}{*}{ RMSPE } & \multirow[b]{2}{*}{$\mathrm{R}^{2}$} & \multicolumn{3}{|c|}{ MSPE bias partition } \\
\hline & Mean & $\mathrm{SE}$ & & & & & Mean & Slope & Random & & & & & Mean & Slope & Random \\
\hline $\mathrm{CP}$ & 3,213 & 767 & 2,935 & 687 & 132.2 & 0.97 & 22.0 & 3.8 & 74.2 & 3,078 & 425 & 130.8 & 0.97 & 6.3 & 8.3 & 85.4 \\
\hline $\mathrm{MCP}^{4}$ & 1,657 & 332 & 1,507 & 488 & 137.2 & 0.82 & 6.5 & 62.5 & 31.0 & 1.705 & 200 & 117.6 & 0.87 & 3.6 & 0.5 & 95.9 \\
\hline RUP & 1,643 & 717 & 1,453 & 298 & 160.5 & 0.95 & 10.3 & 8.8 & 80.9 & 1,406 & 311 & 141.8 & 0.96 & 15.8 & 9.1 & 75.1 \\
\hline $\mathrm{Arg}$ & 138 & 33 & 126 & 31 & 11.0 & 0.88 & 11.9 & 18.6 & 69.5 & 158 & 27 & 11.4 & 0.87 & 28.4 & 10.4 & 61.2 \\
\hline His & 68 & 20 & 60 & 14 & 5.0 & 0.94 & 15.9 & 3.2 & 80.9 & 68 & 11 & 5.6 & 0.92 & 0.3 & 0.6 & 99.1 \\
\hline Ile & 134 & 29 & 127 & 32 & 7.0 & 0.94 & 6.6 & 25.8 & 67.6 & 128 & 19 & 8.3 & 0.91 & 6.0 & 0.1 & 93.9 \\
\hline Leu & 262 & 73 & 225 & 55 & 16.8 & 0.94 & 40.5 & 0.0 & 59.5 & 229 & 44 & 15.5 & 0.95 & 32.2 & 3.4 & 64.4 \\
\hline Lys & 168 & 44 & 160 & 42 & 11.1 & 0.93 & 5.4 & 13.9 & 80.7 & 167 & 26 & 12.3 & 0.91 & 0.1 & 0.9 & 99.0 \\
\hline Met & 54 & 15 & 49 & 11 & 3.7 & 0.93 & 17.6 & 2.6 & 79.8 & 54 & 7 & 4.3 & 0.91 & 0.0 & 0.0 & 100.0 \\
\hline Phe & 141 & 36 & 129 & 30 & 8.8 & 0.93 & 22.8 & 0.9 & 76.3 & 137 & 21 & 8.7 & 0.94 & 2.0 & 3.9 & 94.1 \\
\hline Thr & 131 & 30 & 124 & 29 & 6.8 & 0.95 & 9.3 & 10.6 & 80.1 & 122 & 18 & 6.8 & 0.95 & 14.5 & 0.7 & 84.8 \\
\hline Val & 161 & 41 & 144 & 33 & 10.8 & 0.92 & 23.7 & 2.8 & 73.5 & 149 & 22 & 11.7 & 0.91 & 12.8 & 2.1 & 85.1 \\
\hline $\mathrm{CP}$ & & & 3,252 & 456 & 176.4 & 0.95 & 0.5 & 2.8 & 96.7 & 3,044 & 559 & 138.6 & 0.97 & 12.4 & 1.8 & 85.8 \\
\hline MCP & & & 2,139 & 274 & 121.3 & 0.86 & 68.2 & 5.5 & 26.3 & 1,608 & 293 & 127.9 & 0.84 & 1.4 & 37.0 & 61.6 \\
\hline RUP & & & 1,143 & 239 & 203.9 & 0.91 & 36.3 & 0.0 & 63.7 & 1,468 & 326 & 196.9 & 0.92 & 9.5 & 8.6 & 81.9 \\
\hline Arg & & & 167 & 28 & 11.3 & 0.87 & 48.5 & 7.1 & 44.4 & 122 & 24 & 10.0 & 0.90 & 25.9 & 4.0 & 70.1 \\
\hline His & & & 72 & 13 & 4.8 & 0.94 & 6.0 & 1.1 & 92.9 & 59 & 12 & 5.3 & 0.93 & 21.3 & 0.3 & 78.4 \\
\hline Ile & & & 138 & 21 & 9.2 & 0.89 & 5.6 & 0.1 & 94.3 & 124 & 23 & 7.6 & 0.93 & 25.0 & 0.0 & 75.0 \\
\hline Leu & & & 234 & 44 & 16.0 & 0.95 & 27.7 & 7.4 & 64.9 & 237 & 50 & 15.7 & 0.95 & 27.4 & 4.3 & 68.3 \\
\hline Lys & & & 184 & 31 & 15.1 & 0.87 & 18.2 & 0.3 & 81.5 & 165 & 32 & 12.1 & 0.92 & 1.1 & 0.0 & 98.9 \\
\hline Met & & & 62 & 8 & 4.3 & 0.91 & 29.4 & 0.1 & 70.5 & 49 & 9 & 3.9 & 0.92 & 13.8 & 0.2 & 86.0 \\
\hline Phe & & & 144 & 23 & 9.3 & 0.93 & 2.0 & 6.7 & 91.3 & 130 & 24 & 12.9 & 0.87 & 17.3 & 0.2 & 82.5 \\
\hline Thr & & & 131 & 20 & 7.8 & 0.93 & 0.0 & 0.8 & 99.2 & 124 & 22 & 6.9 & 0.94 & 9.8 & 0.0 & 90.2 \\
\hline Val & & & 159 & 24 & 12.2 & 0.90 & 0.5 & 3.4 & 96.1 & 142 & 26 & 11.2 & 0.92 & 32.1 & 1.5 & 66.4 \\
\hline $\begin{array}{l}{ }^{1} \mathrm{AC}= \\
\text { details } \\
{ }^{2} \mathrm{RMSP} \\
{ }^{3} \mathrm{MSPE} \\
{ }^{4} \mathrm{Microl}\end{array}$ & $\begin{array}{l}\text { minoCor } \\
\text { a the ver } \\
=\text { root } \\
=\text { mean s } \\
\text { al CP. }\end{array}$ & $\begin{array}{l}\text { v; AM } \\
\text { sions } \\
\text { nean } \\
\text { quare }\end{array}$ & $\begin{array}{l}=\text { Agricu } \\
\text { re predic } \\
\text { liction er }\end{array}$ & $\begin{array}{l}\text { oral } \mathrm{M} \\
\text { on err } \\
\text { r witl }\end{array}$ & leling and & aining $\mathrm{S}$ & stems; C & $\mathrm{M}=\mathrm{Co}$ & ell-Penn-M & ersion of & $\mathrm{NCP}$ & $\mathrm{NRC}=\mathrm{N}$ & onal Re & arch Cor & cil (200 & see text $\mathrm{f}$ \\
\hline
\end{tabular}


Table 16. Observed and predicted duodenal flows $(\mathrm{g} / \mathrm{d})$, and statistical adequacy of 4 programs ${ }^{1}$ for rations with high NDF concentration $(\mathrm{NDF}=38.3 \pm 4.9 \% ; \mathrm{n}=55)$

\begin{tabular}{|c|c|c|c|c|c|c|c|c|c|c|c|c|c|c|c|}
\hline \multirow{2}{*}{\multicolumn{2}{|c|}{ Observed }} & \multicolumn{7}{|c|}{$\mathrm{AC}$} & \multicolumn{7}{|c|}{ AMTS } \\
\hline & & \multirow[b]{2}{*}{ Mean } & \multirow[b]{2}{*}{$\mathrm{SE}$} & \multirow[b]{2}{*}{$\mathrm{RMSPE}^{2}$} & \multirow[b]{2}{*}{$\mathrm{R}^{2}$} & \multicolumn{3}{|c|}{ MSPE bias partition ${ }^{3}$} & \multirow[b]{2}{*}{ Mean } & \multirow[b]{2}{*}{ SE } & \multirow[b]{2}{*}{ RMSPE } & \multirow[b]{2}{*}{$\mathrm{R}^{2}$} & \multicolumn{3}{|c|}{ MSPE bias partition } \\
\hline Mean & $\mathrm{SE}$ & & & & & Mean & Slope & Random & & & & & Mean & Slope & Random \\
\hline 2,791 & 837 & 2,760 & 831 & 142.7 & 0.97 & 0.5 & 8.0 & 91.5 & 2,772 & 778 & 129.4 & 0.97 & 0.2 & 2.5 & 97.3 \\
\hline 1,561 & 485 & 1,590 & 494 & 139.7 & 0.91 & 0.6 & 17.2 & 82.2 & 1,534 & 387 & 138.0 & 0.91 & 0.5 & 3.5 & 96.0 \\
\hline 1,235 & 583 & 1,239 & 374 & 202.2 & 0.87 & 2.5 & 0.4 & 97.1 & 1,212 & 380 & 181.6 & 0.90 & 0.4 & 1.0 & 98.6 \\
\hline 106 & 42 & 111 & 36 & 8.7 & 0.96 & 2.6 & 8.5 & 88.9 & 137 & 45 & 9.3 & 0.95 & 37.6 & 16.9 & 45.5 \\
\hline 51 & 20 & 53 & 19 & 5.2 & 0.92 & 2.2 & 10.7 & 87.1 & 58 & 21 & 5.4 & 0.92 & 19.9 & 17.0 & 63.1 \\
\hline 104 & 39 & 120 & 36 & 7.8 & 0.96 & 18.0 & 14.1 & 67.9 & 115 & 34 & 7.6 & 0.96 & 9.0 & 16.7 & 74.3 \\
\hline 188 & 78 & 196 & 66 & 14.1 & 0.96 & 2.4 & 2.2 & 95.4 & 191 & 64 & 14.4 & 0.96 & 0.3 & 2.2 & 97.5 \\
\hline 144 & 55 & 154 & 48 & 9.9 & 0.96 & 6.7 & 4.1 & 89.2 & 150 & 49 & 9.1 & 0.97 & 2.2 & 5.1 & 92.7 \\
\hline 39 & 14 & 44 & 13 & 3.2 & 0.94 & 19.8 & 12.0 & 68.2 & 48 & 14 & 3.1 & 0.94 & 39.7 & 12.9 & 47.4 \\
\hline 112 & 41 & 118 & 37 & 9.2 & 0.95 & 5.0 & 2.5 & 92.5 & 121 & 39 & 9.1 & 0.95 & 10.1 & 4.3 & 85.6 \\
\hline 110 & 39 & 117 & 35 & 6.6 & 0.97 & 4.7 & 6.4 & 88.9 & 108 & 34 & 6.6 & 0.97 & 0.5 & 4.1 & 95.4 \\
\hline \multirow[t]{13}{*}{119} & 47 & 135 & 41 & 7.6 & 0.97 & 14.9 & 6.5 & 78.6 & 132 & 43 & 7.3 & 0.97 & 9.1 & 12.6 & 78.3 \\
\hline & & 2,921 & 758 & 161.9 & 0.96 & 6.8 & 2.1 & 91.1 & 2,721 & 774 & 176.4 & 0.95 & 2.7 & 1.4 & 95.9 \\
\hline & & 1,864 & 483 & 135.7 & 0.92 & 35.9 & 11.2 & 52.9 & 1,478 & 381 & 167.2 & 0.87 & 5.6 & 1.0 & 93.4 \\
\hline & & 1,060 & 345 & 217.0 & 0.85 & 14.4 & 0.2 & 85.4 & 1,270 & 432 & 181.9 & 0.90 & 0.6 & 0.0 & 99.4 \\
\hline & & 144 & 45 & 8.7 & 0.95 & 49.5 & 12.6 & 37.9 & 105 & 31 & 9.3 & 0.95 & 0.0 & 2.0 & 98.0 \\
\hline & & 61 & 22 & 5.2 & 0.93 & 30.0 & 16.6 & 53.4 & 50 & 17 & 6.0 & 0.90 & 0.2 & 2.2 & 97.6 \\
\hline & & 122 & 34 & 7.2 & 0.96 & 21.8 & 12.1 & 66.1 & 111 & 30 & 9.6 & 0.93 & 4.4 & 7.5 & 88.1 \\
\hline & & 195 & 63 & 18.0 & 0.94 & 1.4 & 1.5 & 97.1 & 200 & 64 & 18.0 & 0.94 & 5.0 & 1.1 & 93.9 \\
\hline & & 163 & 50 & 8.3 & 0.98 & 20.8 & 4.2 & 75.0 & 149 & 42 & 11.4 & 0.95 & 2.1 & 0.0 & 97.9 \\
\hline & & 54 & 15 & 2.9 & 0.95 & 61.6 & 10.9 & 27.5 & 43 & 12 & 3.9 & 0.91 & 14.3 & 8.4 & 77.3 \\
\hline & & 125 & 39 & 9.0 & 0.95 & 22.2 & 3.3 & 74.5 & 115 & 34 & 11.0 & 0.92 & 1.1 & 0.0 & 98.9 \\
\hline & & 115 & 34 & 6.0 & 0.97 & 2.6 & 5.0 & 92.4 & 112 & 30 & 8.1 & 0.95 & 0.2 & 1.5 & 98.3 \\
\hline & & 139 & 43 & 6.7 & 0.98 & 20.8 & 10.0 & 69.2 & 127 & 36 & 9.8 & 0.95 & 5.1 & 1.7 & 93.2 \\
\hline
\end{tabular}

${ }^{1} \mathrm{AC}=$ AminoCow; AMTS = Agricultural Modeling and Training Systems; CPM = Cornell-Penn-Miner version of CNCPS; NRC = National Research Council (2001); see text for details on the versions used.

${ }^{2} \mathrm{RMSPE}=$ root mean square prediction error.

${ }^{3} \mathrm{MSPE}=$ mean square prediction error with percentage due to mean, regression, and random disturbance biases.

${ }^{4}$ Microbial CP. 
Table 17. Summary of the evaluation of 4 dairy ration programs to predict duodenal flows of total CP, microbial protein (MCP), RUP, and essential AA ${ }^{1}$

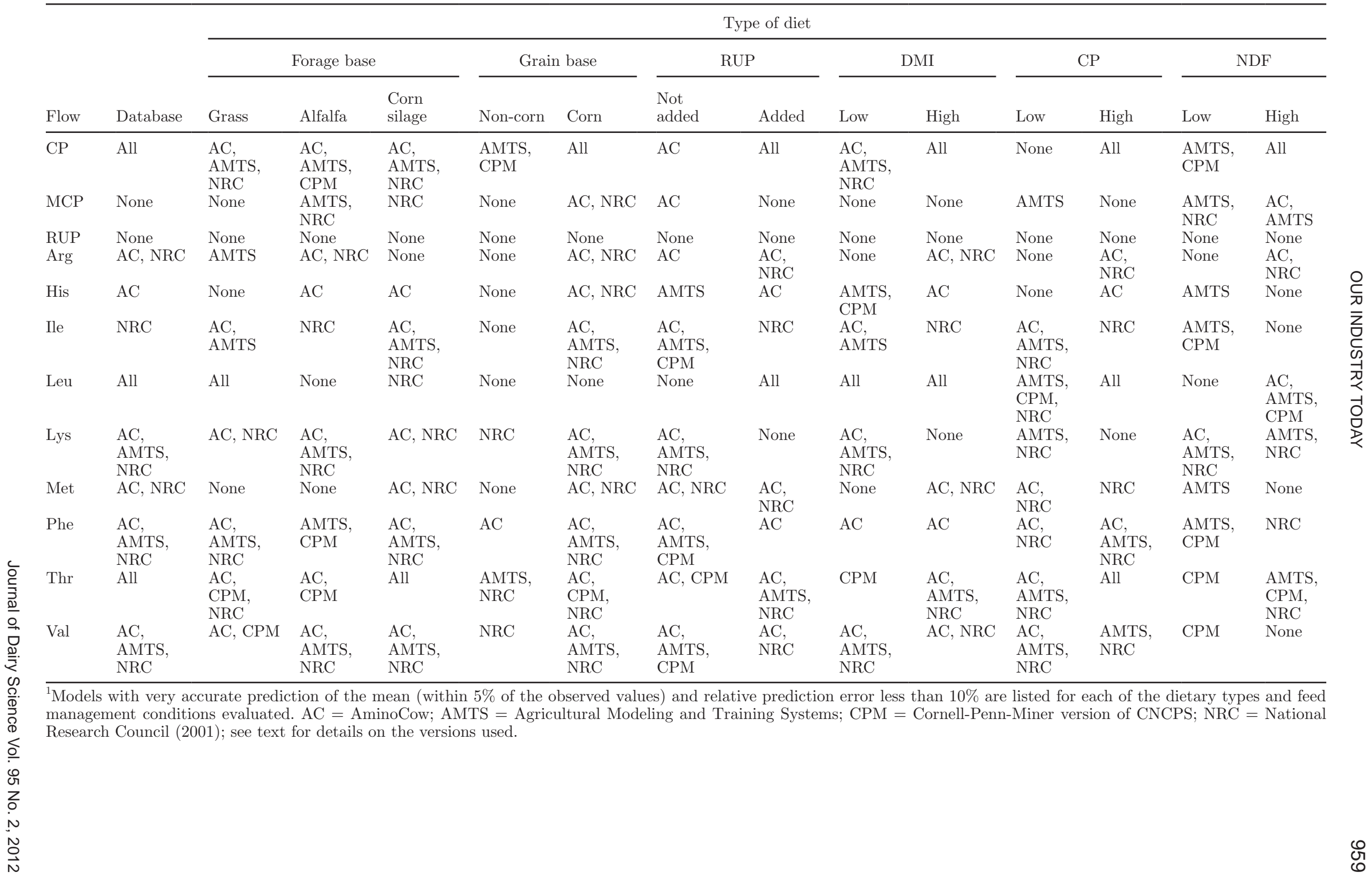


the $\mathrm{B}_{1}, \mathrm{~B}_{2}$, and $\mathrm{B}_{3}$ fractions. The rate of degradation is defined by the in sacco procedure and rate of passage is calculated by the model. Microbial CP is also determined from $\mathrm{kd}$ and $\mathrm{kp}$. Predicted deficiency in ammonia levels will reduce the amount of microbial $\mathrm{CP}$ synthesized proportionally. Predicted levels of rumen peptides are considered stimulatory to non-fiberfermenting bacteria (Fox et al., 2004) and some provision is made in AMTS for urea recycling (Tylutki et al., 2008). Rates of passage are modified by effective NDF (peNDF) and rates of fermentation are modified by predicted rumen $\mathrm{pH}$ (Fox et al., 2004). The AA composition of RUP is determined as the AA composition of the undegraded protein. A large difference between these 2 models is the changes in $\mathrm{kd}$ for protein fractions as well as smaller changes in kp (Tylutki et al., 2008). Neither model attempts to account for the presence of endogenous protein in duodenal CP flow.

On average, CPM slightly overpredicted duodenal CP flows because of considerable overprediction of microbial CP on most ration types investigated. In this study, of the 13 types of rations studied, only in diets where grass was the major forage was microbial CP overpredicted within acceptable limits (14\%). The overprediction of microbial CP by more than $25 \%$ across all diet types resulted in smaller predictions of RUP than were observed, resulting in systematic overpredictions of various EAA compared with the reported values; only Leu flows were underpredicted on average. This situation has been largely corrected in the latest CNCPS model (AMTS). In fact, the AMTS model predicted within $3 \%$ of observed microbial $\mathrm{CP}$ and did it with the lowest RMSPE of all the models and the highest partition of MSPE in random disturbance, indicating a very robust and precise model for microbial $\mathrm{CP}$ synthesis. A similar situation exists for RUP, with AMTS having the smallest RMSPE of all models for this protein fraction. Overall, AMTS predicted a slightly greater flow for total EAA, but that mainly originated from overprediction of Arg and, to a lesser extent, Met. In 10 of the 13 ration types, AMTS overpredicted Arg outside acceptable limits, and this was by an average of $26 \%$. Methionine was overpredicted in 4 ration types (alfalfa-based, non-corn-based, low CP, and high NDF diets) and was just barely acceptable in 4 other ration types (no added RUP, added RUP, high DMI, and high $\mathrm{CP}$ ) and equal to CPM for having the highest RMSPE for Met. It is not possible from the data in hand to understand why the prediction of Arg and Met should behave in this manner, although because the percentage of microbial CP is different for these diets, we suggest that the assumed concentration of Arg and Met in RUP of ingredient(s) might have been overestimated.

\section{AC Model}

The AC model requires fewer inputs than the other models. Dietary protein is broken into RDP and RUP similar to the sixth revised edition of NRC (1989), but using the RDP as determined by the Streptomyces griseus assay (Evonik Industries GmbH, 2007b) and assuming that RDP plus RUP percentages equal to $100 \%$ of CP. The RUP arriving at the duodenum is calculated as CP amount times the RUP percentage, with an adjustment for DMI. The AA composition of RUP is assumed to be the same as for the feed ingredient protein. Microbial CP is considered one homogeneous mass and is predicted from the truly digestible nutrients of the entire daily diet, as described in the seventh edition of NRC (2001). No provision is made for urea recycling, a peptide effect, or asynchrony between carbohydrates and rumen N. However, a deduction of microbial CP is taken when predicted RDP supply is negative. This deduction is curvilinear, with greater deductions as the calculated RDP deficiency becomes greater. Endogenous protein is calculated, and an AA composition of this protein is assumed as constant (Evonik Industries GmbH, 2007a).

Although AC predicted RUP with acceptable accuracy, it underestimated microbial $\mathrm{CP}$ on 2 diet types (low DMI and low CP diets). Inspection of these rations indicated that the deduction made on microbial $\mathrm{CP}$ might be too large when the model-calculated RDP deficiency was greater than $-0.54 \mathrm{~kg}$. Additionally, AC underpredicted His flow by more than $10 \%$ on grassbased, non-corn-based starch, low intake, low CP, and low NDF diets. These diets were generally of low intake, suggesting that AC may not account appropriately for the His contribution from microbial CP. Arginine on grass-based diets was also underpredicted, but because it was not underpredicted on other low DMI diets, this could reflect an error in the Arg concentration assumed for grasses.

\section{NRC Model}

The NRC model may be looked at as intermediate in complexity between the CNCPS models and the AC model. The NRC model uses 3 fractions of CP, based on in situ ruminal protein degradation (NRC, 2001). Protein fraction A is completely rumen degradable, fraction $\mathrm{C}$ is completely undegradable in the rumen, yielding fraction $\mathrm{B}$, which is potentially degradable in the rumen. Fractions are determined by curve peeling of individual ingredients by the in sacco technique. Degradation constants are determined in a similar manner. Passage rates are calculated depending on whether the 
ingredient is concentrate or forage (dry or wet). Microbial CP yield is calculated from discounted total digestible nutrients. Essential AA of feeds are considered to be the same for the RUP fraction. Endogenous CP is calculated, but like microbial $\mathrm{CP}$, the AA composition is not reported. The EAA flows are determined by regression equations relating the percentage of $\mathrm{AA}$ in duodenal flow to percentage of each EAA in RUP and percentage of RUP in duodenal flow, and then multiplying the percentage of EAA in duodenal flow by $\mathrm{CP}$ duodenal flow (NRC, 2001).

The NRC model predicted mean microbial CP and RUP closer to observed values than the other models, although generally with greater RMSPE than either $\mathrm{AC}$ or AMTS. The predictions of AA were, on average, slightly underestimated, but NRC had the lowest slope bias compared with the other models. On average, flows of Arg and His were underpredicted to a greater degree under "low" supply conditions compared with their "high" counterpart (i.e., grass-based vs. corn silage-based diets; non-corn-based vs. corn-based diets; no added vs. added RUP; low vs. high intake; low vs. high protein; low vs. high NDF). Because AC and NRC use a common data set for AA composition of feeds and because RUP flows were predicted close to observed, the Arg underprediction could be due to underestimation in feed protein, whereas the His underprediction occurs as a result of underestimation in both feed and microbial protein. Other than underprediction of Arg and His, the NRC model proved to be very robust across the different diet groups, with smaller mean and slope biases than the other models.

\section{Other Considerations}

It is interesting to note the close approximation of model-predicted DMI to that actually observed. However, model predictions of DMI were within $1.5 \mathrm{~kg}$ of measured in only $61,50,49$, and $58 \%$ of the diets (by AC, AMTS, CPM, and NRC, respectively). This suggests that accurately balancing AA in dairy rations may not be easy to achieve unless actual DMI is determined. Using the estimated DMI values from the models to provide protein supply could result in both over- and underfeeding of protein in practical situations. It is also interesting to note that individual diets that had a poor prediction of DMI in one model seemed to have a poor predictions in other models. Likewise, in general terms, all models tended to have more problems accurately predicting some AA than others. This was particularly noticeable for Arg, His, Ile, and Met, which appear to be predicted with more biases than Leu, Lys, Val, Thr, and Phe. This may suggest that applying similar constants (i.e., similar biology) to all
AA may be in error. For example, across all diets, Leu was underpredicted by all models (Table 2). However, this underprediction by all models was not present with non-corn-based diets but was consistently present with corn-based diets. This suggests that Leu, present in high concentration in corn protein, might have greater concentrations than those used in the model database, or Leu is less degraded in the rumen than the other $\mathrm{AA}$ in these types of diet. It is also of interest that in terms of mean prediction and RMSPE, adding more protein fractions did not greatly increase the precision or accuracy of RUP prediction. This may mean less variation in RUP of specific proteins or a lack of basic knowledge as to how proteins are actually degraded by various rumen populations.

Finally, the results of this study must be viewed with some caution. For example, NRC may appear to be best at predicting the means of the measured protein fractions with the lowest bias because unreported feed ingredient values were taken from NRC. In addition, it should be acknowledged that data necessary for the full function of the CNCPS models was not available. It may well be that adding these inputs would improve the accuracy or reduce the RMSPE of the CNCPSbased models. However, except for CPM, the other models appeared to predict with sufficient accuracy and without bias except in those situations already detailed. With the exception of those AA already noted, the models appear adequate for use in routine ration work if the actual DMI is determined. It is encouraging that AC, AMTS, and NRC accurately predicted the means of observed AA flow and predicted as close to each other as they did, and that the RMSPE and error partitioning were also close. This implies that nutritionists have tools available so that AA balance and subsequent protein savings should begin in earnest.

\section{CONCLUSIONS}

No model was clearly superior to the others; all have areas where significant improvements can be achieved, as summarized in Table 17. With the possible exception of CPM, commercially available nutritional models can accurately predict the flow of EAA to the duodenum, although EAA flows are better predicted on corn-based diets than on other diet types. Although all models need improvement, some of which were detailed in this analysis, it is clear that model errors in the prediction of duodenal EAA flows are not a large barrier for adoption of EAA balance in diets for dairy cattle.

\section{ACKNOWLEDGMENTS}

The authors gratefully acknowledge Evonik Industries AG (Hanau, Germany) for partial financial support of this study. 


\section{REFERENCES}

Baldwin, R. L., J. H. Thornley, and D. E. Beever. 1987. Metabolism of the lactating cow. II. Digestive elements of a mechanistic model. J. Dairy Res. 54:107-131.

Bateman, H. G., J. H. Clark, R. A. Patton, C. J. Peel, and C. G. Schwab. 2001. Prediction of crude protein and amino acid passage to the duodenum of lactating cows by models compared with in vivo data. J. Dairy Sci. 84:665-679.

Bibby, J., and H. Toutenburg. 1977. Pages 16-19 in Prediction and Improved Estimation in Linear Models. John Wiley \& Sons, London, UK.

Broderick, G. A., M. J. Stevenson, and R. A. Patton. 2009. Effect of dietary protein concentration and degradability on response to rumen-protected methionine in lactating dairy cows. J. Dairy Sci. 92:2719-2728.

Broderick, G. A., M. J. Stevenson, R. A. Patton, N. E. Lobos, and J J. Olmos Colmenero. 2008. Effect of supplementing rumen-protected methionine on production and nitrogen excretion in lactating dairy cows. J. Dairy Sci. 91:1092-1102.

Dijkstra, J., H. Neal, D. Beever, and J. France. 1992. Simulation of nutrient digestion, absorption and outflow in the rumen: Model description. J. Nutr. 122:2239-2256.

Evonik Degussa Industries GmbH. 2007a. AminoCow, the Mepron Dairy Ration Evaluator, Help File. Evonik Industries, Hanau, Germany.

Evonik Degussa Industries GmbH. 2007b. Philosophy of Amino Cow. Evonik Industries, Hanau, Germany.

Fox, D. G., L. O. Tedeschi, T. P. Tylutki, J. B. Russel, M. E. Van Amburgh, L. E. Chase, A. N. Pell, and T. R. Overton. 2004. The Cornell Net Carbohydrate and Protein System model for evaluating herd nutrition and nutrient excretion. Anim. Feed Sci. Technol. 112:29-78.

INRA. 1989. Ruminant nutrition. Recommended allowances and feed tables. Institut National de la Recherche Agronomique, John Libbey Eurotext, Montrouge, France.

Kohn, R. A., K. F. Kalscheur, and M. Hanigan. 1998. Evaluation of models for balancing the protein requirements of dairy cows. J. Dairy Sci. 81:3402-3414.

Kolver, E. S., L. D. Muller, M. C. Barry, and J. W. Penno. 1998 Evaluation and application of the Cornell Net Carbohydrate and Protein System for dairy cows fed diets based on pasture. J. Dairy Sci. 81:2029-2039

Lanzas, C., L. O. Tedeschi, S. Seo, and D. G. Fox. 2007. Evaluation of protein fractionation systems used in formulating rations for dairy cows. J. Dairy Sci. 90:507-521.

Lescoat, P., and D. Sauvant. 1995. Development of a mechanistic model for rumen digestion validated using the duodenal flux of amino acids. Reprod. Nutr. Dev. 35:45-70.

McNamara, J. P. 2004. Research, improvement and application of mechanistic, biochemical dynamic models of metabolism in lactating dairy cattle. Anim. Feed Sci. Technol. 112:155-176.

National Research Council. 1978. Nutrient Requirements of Dairy Cattle. 5th rev. ed. Natl. Acad. Sci., Washington, DC.

National Research Council. 1989. Nutrient Requirements of Dairy Cattle. 6th rev ed. Natl. Acad. Sci., Washington, DC.

National Research Council. 2001. Nutrient Requirements of Dairy Cattle. 7th rev. ed. Natl. Acad. Sci., Washington, DC.

O'Connor, J. D., C. J. Sniffen, D. G. Fox, and W. Chalupa. 1993. A net carbohydrate and protein system for evaluating cattle diets: IV. Predicting amino acid adequacy. J. Anim. Sci. 71:1298-1311.

Pacheco, D., C. G. Schwab, R. Berthiaume, G. Raggio, and H. Lapierre. 2006. Comparison of net portal absorption with predicted flow of digestible amino acids: Scope for improving current models? J. Dairy Sci. 89:4747-4757.

Patton, R. A. 2010. Effect of rumen-protected methionine on feed intake, milk production, true milk protein concentration, and true milk protein yield, and the factors that influence these effects: A meta-analysis. J. Dairy Sci. 93:2105-2118.

Sniffen, C. J., J. D. O'Connor, P. J. Van Soest, D. G. Fox, and J. B. Russell. 1992. A net carbohydrate and protein system for evaluat- ing cattle diets. Part II. Carbohydrate and protein availability. J. Anim. Sci. 71:1339-1352.

St-Pierre, N. R. 2001. Integrating quantitative findings from multiple studies using mixed model methodology. J. Dairy Sci. 84:741-755.

Tylutki, T. P., D. G. Fox, V. M. Durbal, L. O. Tedeschi, J. B. Russell, M. E. Van Amburgh, T. R. Overton, L. E. Chase, and A. N. Pell. 2008. Cornell Net Carbohydrate and Protein System: A model for precision feeding of dairy cattle. Anim. Feed Sci. Technol. 143:174-202.

Von Keyserlingk, M. A. G., M. L. Swift, and J. A. Shelford. 1999. Evaluation and application of the Cornell Net Carbohydrate and Protein System and rumen-protected methionine to maintain milk production in cows receiving reduced protein diets. Can. J. Anim. Sci. 79:397-400.

Yu, P., D. A. Christensen, and J. J. McKinnon. 2003. Comparison of the National Research Council-2001 model with the Dutch system (DVE/OEB) in the prediction of nutrient supply to dairy cows from forages. J. Dairy Sci. 86:2178-2192.

\section{APPENDIX}

References for studies used in the prediction of duodenal flow of proteins and essential amino acids

Aldrich, J. M., L. D. Muller, G. A. Varga, and L. C. Griel. 1993. Nonstructural carbohydrate and protein effects on rumen fermentation, nutrient flow, and performance of dairy cows. J. Dairy Sci. 76:1091-1105

Armentano, L. E., T. A. Herrington, C. E. Polan, A. J. Moe, J. H Herbein, and P. Umstadt. 1986. Ruminal degradation of dried brewers grains, wet brewers grains, and soybean meal. J. Dairy Sci. 69:2124-2133.

Benchaar, C., M. Vernay, C. Bayourthe, and R. Moncoulon. 1994. Effects of extrusion of whole horse beans on protein digestion and amino acid absorption in dairy cows. J. Dairy Sci. 77:1360-1371.

Bernard, J. K., P. T. Chandler, J. W. West, A. H. Parks, H. A. Amos, M. A. Froetschel, and D. S. Trammell. 2004. Effect of supplemental L-lysine- $\mathrm{HCl}$ and corn source on rumen fermentation and amino acid flow to the small intestine. J. Dairy Sci. 87:399-405.

Cameron, M. R., T. H. Klusmeyer, G. L. Lynch, J. H. Clark, and D R. Nelson. 1991. Effects of urea and starch on rumen fermentation, nutrient passage to the duodenum, and performance of cows. J. Dairy Sci. 74:1321-1336.

Christensen, R. A., M. R. Cameron, T. H. Klusmeyer, J. P. Elliott, J. H. Clark, D. R. Nelson, and Y. Yu. 1993. Influence of amount and degradability of dietary protein on nitrogen utilization by dairy cows. J. Dairy Sci. 76:3497-3513

Christensen, R. A., T. R. Overton, J. H. Clark, J. K. Drackley, D. R. Nelson, and S. A. Blum. 1996. Effects of dietary fat with or without nicotinic acid on nutrient flow to the duodenum of dairy cows. J. Dairy Sci. 79:1410-1424

Cunningham, K. D., M. J. Cecava, and T. R. Johnson. 1993. Nutrient digestion, nitrogen, and amino acid flows in lactating cows fed soybean hulls in place of forage or concentrate. J. Dairy Sci. 76:3523-3535.

Cunningham, K. D., M. J. Cecava, and T. R. Johnson. 1994. Flows of nitrogen and amino acids in dairy cows fed diets containing supplemental feather meal and blood meal. J. Dairy Sci. 77:3666-3675.

Cunningham, K. D., M. J. Cecava, T. R. Johnson, and P. A. Ludden 1996. Influence of source and amount of dietary protein on milk yield by cows in early lactation. J. Dairy Sci. 79:620-630.

Erasmus, L. J., P. M. Botha, and A. Kistner. 1992. Effect of yeast culture supplement on production, rumen fermentation, and duodenal nitrogen flow in dairy cows. J. Dairy Sci. 75:3056-3065.

Erasmus, L. J., P. M. Botha, and H. H. Meissner. 1994. Effect of protein source on ruminal fermentation and passage of amino acids to the small intestine of lactating cows. J. Dairy Sci. 77:3655-3665.

Ipharraguerre, I. R., J. H. Clark, and D. E. Freeman. 2005a. Varying protein and starch in the diet of dairy cows. I. Effects on rumi- 
nal fermentation and intestinal supply of nutrients. J. Dairy Sci. $88: 2537-2555$

Ipharraguerre, I. R., J. H. Clark, and D. E. Freeman. 2005b. Rumen fermentation and intestinal supply of nutrients in dairy cows fed rumen-protected soy products. J. Dairy Sci. 88:2879-2892.

Ipharraguerre, I. R., Z. Shabi, J. H. Clark, and D. E. Freeman. 2002 Ruminal fermentation and nutrient digestion by dairy cows fed varying amounts of soyhulls as a replacement for corn grain. J. Dairy Sci. 85:2890-2904.

Jones-Endsley, J. M., M. J. Cecava, and T. R. Johnson. 1997. Effects of dietary supplementation on nutrient digestion and the milk yield of intensively grazed lactating dairy cows. J. Dairy Sci. 80:3283-3292.

King, K. J., J. T. Huber, M. Sadik, W. G. Bergen, A. L. Grant, and V. L. King. 1990. Influence of dietary protein sources on the amino acid profiles available for digestion and metabolism in lactating cows. J. Dairy Sci. 73:3208-3216.

Klusmeyer, T. H., G. L. Lynch, J. H. Clark, and D. R. Nelson. 1991. Effects of calcium salts of fatty acids and protein source on ruminal fermentation and nutrient flow to duodenum of cows. J. Dairy Sci. 74:2206-2219.

Klusmeyer, T. H., G. L. Lynch, J. H. Clark, and D. R. Nelson. 1991. Effects of calcium salts of fatty acids and proportion of forage in diet on ruminal fermentation and nutrient flow to duodenum of cows. J. Dairy Sci. 74:2220-2232.

Klusmeyer, T. H., R. D. McCarthy Jr., J. H. Clark, and D. R. Nelson. 1990. Effects of source and amount of protein on ruminal fermentation and passage of nutrients to the small intestine of lactating cows. J. Dairy Sci. 73:3526-3537.

Kung, L. Jr., J. T. Huber, W. G. Bergen, and D. Petitclerc. 1984 Amino acids in plasma and duodenal digesta and plasma growth hormone in cows fed varying amounts of protein of differing degradability. J. Dairy Sci. 67:2519-2524.

Larsen, M., T. G. Madsen, M. R. Weisbjerb, T. Hvelplund, and J. Madsen. 2000. Endogenous amino acid flow in the duodenum of dairy cows. Acta Agric. Scand. A Anim. Sci. 50:161-173.

Mabjeesh, S. J., A. Arieli, I. Bruckental, S. Zamwell, and H. Tagari. 1996. Effect of type of protein supplementation on duodenal amino acid flow and absorption in lactating dairy cows. J. Dairy Sci. 79:1792-1801.

Mansfield, H. R., and M. D. Stern. 1994. Effects of soybean hulls and lignosulfonate-treated soybean meal, on ruminal fermentation in lactating dairy cows. J. Dairy Sci. 77:1070-1083.

McCarthy, R. D., Jr., T. H. Klusmeyer, J. L. Vicini, J. H. Clark, and D. R. Nelson. 1989. Effects of source of protein and carbohydrate on ruminal fermentation and passage of nutrients to the small intestine of lactating cows. J. Dairy Sci. 72:2002-2016.

Narasimhalu, P., E. Teller, M. Vanbelle, M. Foulon, and F. Dasnoy 1989. Apparent digestibility of nitrogen in rumen and whole tract of Friesian cattle fed direct-cut and wilted grass silages. J. Dairy Sci. 72:2055-2061.

O'Mara, F. P.. J. J. Murphy, and M. Rath. 1998. Effect of amount of dietary supplement and source of protein on milk production, ruminal fermentation, and nutrient flows in dairy cows. J. Dairy Sci. 81:2430-2439.

O'Mara, F. P., G. K. Stakelum, P. Dillon, J. J. Murphy, and M. Rath. 1997. Rumen fermentation and nutrient flows for cows fed grass and grass supplemented with molassed beet pulp pellets. J. Dairy Sci. 80:2466-2474.

Overton, T. R., M. R. Cameron, J. P. Elliott, J. H. Clark, and D. R. Nelson. 1995. Ruminal fermentation and passage of nutrients to the duodenum of lactating cows fed mixture of corn and barley. J. Dairy Sci. 78:1981-1998.

Prance, R. W., M. D. Stern, N. A. Jorgensen, and L. D. Setter. 1984. Site and extent of protein digestion in lactating cows fed alfalfa silage or baled alfalfa hay. J. Dairy Sci. 67:2308-2314.

Putnam, D. E., C. G. Schwab, M. T. Sochi, N. L. Whitehouse, N. A. Kierstead, and B. D. Garthwaite. 1997. Effect of yeast culture in the diets of early lactation dairy cows on ruminal fermentation and passage of nitrogen fractions and amino acids to the small intestine. J. Dairy Sci. 80:374-384.

Robinson, P. H. 1997. Modifying duodenal flow of amino acids by manipulation of dietary protein sources. Can. J. Anim. Sci. 77:241251

Santos, K. A., M. D. Stern, and L. D. Satter. 1984. Protein degradation in the rumen and amino acid absorption in the small intestine in lactating dairy cattle fed various protein sources. J. Anim. Sci. $58: 244-255$.

Stern, M. D., L. M. Rode, R. W. Prange, R. H. Stauffacher, and L. D. Satter. 1983. Ruminal protein degradation of corn gluten meal in lactating dairy cattle fitted with duodenal T-type cannulae. J. Anim. Sci. 56:194-205.

Tagari, H., A. Arieli, S. Mabjeesh, I. Bruckental, S. Zamwell, and Y. Aharoni. 1995. Assessment of duodenal amino acid profile in dairy cows by the in situ method. Livest. Prod. Sci. 42:13-22.

Van Vuuren, A. M., C. J. Van Der Koelen, and J. Vroons-De Bruin. 1993. Ryegrass versus corn starch or beet pulp fiber diet effects on digestion and intestinal amino acids in dairy cows. J. Dairy Sci. $76: 2692-2700$

Volden, H. 1999. Effects of level of feeding and ruminally undegraded protein on ruminal bacterial protein synthesis, escape of dietary protein, intestinal amino acid profile, and performance of dairy cows. J. Anim. Sci. 77:1905-1918.

Waltz, D. M., M. D. Stern, and D. J. Illg. 1989. Effect of ruminal protein degradation of blood meal and feather meal on the intestinal amino acid supply to lactating cows. J. Dairy Sci. 72:1509-1518.

Yang, W. Z., and K. A. Beauchemin. 2004. Grain processing, forageto-concentrate ratio, and forage length effects on ruminal nitrogen degradation and flows of amino acids to the duodenum. J. Dairy Sci. 87:2578-2590.

Zerbini, E., C. E. Polan, and J. H. Herbein. 1988. Effect of dietary soybean meal and fish meal on protein digesta flow in Holstein cows during early and midlactation. J. Dairy Sci. 71:1248-1258. 